\title{
Early life trauma and attachment: immediate and enduring effects on neurobehavioral and stress axis development
}

\section{Millie Rincón-Cortés ${ }^{1,2,3}$ * and Regina M. Sullivan ${ }^{1,2,3}$}

${ }^{1}$ Department of Neuroscience and Physiology, Sackler Institute for Graduate Biomedical Sciences, New York University School of Medicine, New York, NY, USA

2 Emotional Brain Institute, Nathan Kline Institute for Psychiatric Research, New York, NY, USA

${ }^{3}$ New York University Child Study Center, Department of Child and Adolescent Psychiatry, New York University School of Medicine, New York, NY, USA

\section{Edited by:}

Nikolaos P. Daskalakis, Icahn School of Medicine at Mount Sinai, USA

\section{Reviewed by:}

Aniko Korosi, University of Amsterdam, Netherlands

James A. Carr, Texas Tech University, USA

\section{*Correspondence:}

Millie Rincón-Cortés, Sullivan Laboratory, New York University Child Study Center, Department of Child and Adolescent Psychiatry, New York University School of Medicine, 1 Park Avenue, New York, NY 10016, USA e-mail:millie.rinconcortes@ med.nyu.edu
Over half a century of converging clinical and animal research indicates that early life experiences induce enduring neuroplasticity of the HPA-axis and the developing brain. This experience-induced neuroplasticity is due to alterations in the frequency and intensity of stimulation of pups' sensory systems (i.e., olfactory, somatosensory, gustatory) embedded in mother-infant interactions. This stimulation provides "hidden regulators" of pups' behavioral, physiological, and neural responses that have both immediate and enduring consequences, including those involving the stress response. While variation in stimulation can produce individual differences and adaptive behaviors, pathological early life experiences can induce maladaptive behaviors, initiate a pathway to pathology, and increase risk for later-life psychopathologies, such as mood and affective disorders, suggesting that infant-attachment relationships program later-life neurobehavioral function. Recent evidence suggests that the effects of maternal presence or absence during this sensory stimulation provide a major modulatory role in neural and endocrine system responses, which have minimal impact on pups' immediate neurobehavior but a robust impact on neurobehavioral development. This concept is reviewed here using two complementary rodent models of infant trauma within attachment: infant paired-odor-shock conditioning (mimicking maternal odor attachment learning) and rearing with an abusive mother that converge in producing a similar behavioral phenotype in later-life including depressive-like behavior as well as disrupted HPA-axis and amygdala function. The importance of maternal social presence on pups' immediate and enduring brain and behavior suggests unique processing of sensory stimuli in early life that could provide insight into the development of novel strategies for prevention and therapeutic interventions for trauma experienced with the abusive caregiver.

Keywords: infant-attachment, maternal programming, development, amygdala, social behavior, rodent models, stress

\section{INTRODUCTION}

Both animal and human research demonstrate that early life experiences interact with genetics to program the central nervous and endocrine systems, including the hypothalamus-pituitaryadrenal (HPA)-axis (1-5). Infant experiences typically occur within the context of the mother and the quality of caregiving by the mother, determined by the patterning and intensity of maternal stimulation of pups' sensory systems, is a key regulator of HPA-axis neuroplasticity in the neonatal period (6-10). Dissecting the mother-infant dyad has characterized maternal control over infant brain and behavior through "hidden regulators" present during mother-infant interactions $(11,12)$. Lack or loss of typical parental stimulation is a potent stressor during early life $(13,14)$, and removal of these hidden regulators through maternal deprivation, modulation of maternal behavior, and/or traumatic interactions with the mother, produce immediate changes in pups and result in wide-spread dysregulation of physiological and behavioral responses during development (15-26). Within the range of typical parenting, normal variations in maternal care during infancy program individual differences in behavioral and endocrine responses to stress in rodents and humans; although pathological experiences, including abuse and neglect, produce vulnerability to later-life psychiatric disorders (7, 27-37).

Here, we focus on infant experiences and the effects of early life stress and HPA-axis activation as experienced within the motherinfant dyad, as well as the pups' attachment to the caregiver and learning about the caregiver. We review two complementary rodent models of infant trauma within attachment: infant pairedodor-shock conditioning and rearing with an abusive mother, which converge in producing a similar neurobehavioral phenotype in later-life consisting of depressive-like behavior as well as disrupted HPA-axis and amygdala function, thus enabling us to explore both the immediate and enduring effects of abusive attachment as well as role of the HPA-axis and the stress hormone corticosterone (CORT). Although infant trauma resulting from abusive attachment affects neural substrates of stress vulnerability and resilience, these can be engaged by sensory cues learned 
during infancy (i.e., artificial or natural maternal odor), which have the ability to normalize adult neurobehavioral dysregulation stemming from early life trauma.

\section{ATTACHMENT}

Attachment is a psychosocial process referring to the deep and enduring emotional bond that connects two individuals across space and time, with an individual deriving security from physical and psychological contact with the attachment figure (38-40). Attachment requires experience-dependent learning of the sensory stimuli associated with infant-caregiver interactions, and a strong attachment to the caregiver is crucial for survival in altricial species, including humans (41-48). In children, attachment is characterized by specific behaviors such as seeking proximity to the caregiver, whom provides a sense of safety and security for the infant (49-51). Like humans, infants from altricial species also exhibit attachment related behaviors to their caregiver shortly after birth that elicit nurturing and attachment from the caregiver, which entails responding appropriately to the infant's needs by providing nourishment, protection, and warmth necessary for survival (51-53). Thus, infant-attachment is an adaptive and reciprocal process consisting of a dynamic and complex exchange of mother-infant behavioral interactions that enhance the infant's chance of survival by maintaining contact with the caregiver.

The mother-infant attachment bond is among the strongest social attachments formed by most mammals (54). As such, human infants seek proximity to and maintain contact with the caregiver despite the quality of care they receive (55), including attachment to an abusive caregiver. This paradoxical phenomenon also occurs in dogs, chicks, and non-human primates, suggesting a phylogenetically preserved system $(32,41,43,56-63)$. From an evolutionary perspective, attachment to an abusive caregiver is thought to be adaptive because it provides immediate benefits, as the infant still has access to some care $(48,64)$. Albeit infant organisms are biologically predisposed to attach to their caregiver and possess behavioral systems that allow them to rely on these bonds for survival (38), clinical and preclinical studies suggest that adverse parental care compromises brain development and has longstanding effects in stress-responsive neurobiological systems, including the HPA-axis, neurotransmitter systems, as well as cortical and limbic structures such as the prefrontal cortex, amygdala, and hippocampus (65-75). Moreover, traumatic early life experiences involving the caregiver increase the risk for a wide-range of deleterious mental health and behavioral outcomes, including developmental psychopathology, affective, and mood disorders (37, 72, 76-86). Therefore, perturbations in infant-attachment appear to induce immediate neurobiological changes that shape subsequent development and lead to neurobehavioral dysregulation associated with compromised emotionality and increased vulnerability to psychopathology during later-life, suggesting that the quality of an infant's first social relationships programs the infant's emotional and cognitive capabilities to adapt to later-life environments.

Despite the fact that childhood abuse remains a major public health concern (87-91), the mechanisms by which infant trauma initiates the pathway to psychopathology are poorly understood, although the stress axis is evidently implicated. However, animal models have provided some insight into the mechanisms by which disruptions in parental care alter the development of stress response systems $(92,93)$, which may contribute to our understanding of resilience following infant trauma (62, 94-98). For example, research using animal models of maternal deprivation in rodents and non-human primates parallel human imaging studies suggesting that disruptions in infant-attachment also produce long-term alterations in the limbic system and the stress axis that may compromise the development of emotion- and attentionregulatory systems, which has been used to explain the heightened risk of behavioral and affective disorders in human children experiencing adverse parental care $(13,31,32,75,93,99-108)$. Overall, these studies demonstrate that parental care affects the maturation of these brain areas and offers potential sites to understand the damaging effects of early life abuse on subsequent neurobehavioral development $(31,70,71,74,84,94,109-115)$. For these reasons, we employ rodent models of abusive attachment and study the infant's immediate response to trauma as well as the neurobiological sequelae leading to later-life neurobehavioral dysregulation to better understand the infant mechanisms that initiate the pathway to later-life psychopathologies.

\section{THE STRESS-HYPORESPONSIVE PERIOD AND MATERNAL REGULATION OF THE HPA-AXIS}

In rats, infant-attachment occurs within a unique developmental context - the stress-hyporesponsive period (SHRP) - during which neonates show low basal plasma concentrations of CORT and reduced stress-reactivity, as indexed by limited adrenocorticotropic hormone (ACTH) and CORT responses to stressful stimuli compared to older animals, as well as low levels of corticosteroid binding globulin (CBG), which regulates glucocorticoid (GC) access into the brain $(92,116-123)$. Thus, the neuroendocrine stress response of the neonatal rat is characterized by attenuated hormonal responses and altered gene regulation in response to stress compared to adults due to hyporesponsiveness at all levels of the HPA-axis, namely: (1) a blunted pituitary ACTH secretion, resulting from a combination of immaturity of neural inputs to the corticotropin releasing hormone (CRH) neurons, (2) decreased pituitary peptide content or decreased sensitivity to CRH stimulus; and (3) an adrenal gland hyporesponsive to circulating ACTH levels (18, 119, 121, 124-130). Accumulating evidence suggests that human infants exhibit a period of dampened cortisol reactivity analogous to the rodent SHRP, which develops gradually over the course of the first year of life ( $\sim-12$ months), although it remains unclear how long it extends (131-135). In both humans and rodents, the SHRP is thought to protect the developing brain from the detrimental effects of elevated HPA-axis activity and excess GC exposure, and the sensitivity and responsiveness from the caregiver appears critical in maintaining low cortisol activity and controlling the offspring's physiological and behavioral responses to stressors during this period $(3,30,32,68$, $100,122,127,129,136-140)$.

However, the SHRP during development appears to be stressor specific, since the HPA-axis is fully capable of responding to stimuli that may be considered stressful to a neonatal rat such as cold or saline injection (141-145). Indeed, the HPA-axis and CORT receptors are functional at birth, but are modulated by 
the sensory stimulation provided by the mother $(100,119,126$, 146-152). Moreover, the mother is able to directly regulate the pups' CORT levels through hidden regulators embedded in typical mother-infant interactions, such as the sensory, motor, nutrient, and thermal events associated with caregiving, which exert regulatory influence over the infant's immediate and long-term behavioral and physiological responses by affecting sleep-wake states, cardiac rates, and HPA-axis function $(6,10-12,17,129,153,154)$. Removal of maternal sensory stimulation during the SHRP, such as that occurring when the pups are separated from the mother for a prolonged period of time (i.e., maternal deprivation paradigm), increases CORT secretion (16), elevates CORT levels in pups (11, 12, 129), and enables higher CORT/ACTH responses to acute stress $(15,19,100,145,155)$. Importantly, these changes are similar to those induced by normal variations in maternal care (i.e., maternal high/low licking paradigm) $(7,27,29)$ as well as atypical or abusive maternal care $(20,144,156)$, suggesting that the hypothalamic mechanisms controlling physiological stress responses in the pup are regulated by elements of maternal care. Taken together, these findings suggest that maternal deprivation, variations in maternal care, and abusive maternal care influence the development and function of the HPA-axis $(8,9,30,112,114,157-160)$. In summary, maternal stimulation modulates the infant's HPA-axis and maintains the SHRP, although potent stressors involving disruptions in maternal stimulation (i.e., cold, maternal deprivation, atypical maternal care) can activate the HPA-axis and override maternal control of the SHRP.

\section{ATTACHMENT LEARNING DURING A SENSITIVE-PERIOD IN RAT PUPS}

Infants possess a predisposition to approach the mother as well as specific sensory cues associated with her care, such as her odor and vocalizations $(161,162)$. Within an evolutionary context, the infant-attachment system serves to establish a preference for the mother regardless of whether or not she is associated with pain or pleasure $(48,64)$. This type of survival-dependent learning is known as imprinting, has wide phylogenetic representation, and is temporally confined to a sensitive-period in development $(50,161$, 163) typically involving a hypofunctioning HPA-axis - the principal pathway of the mammalian stress response that regulates the production of GCs (cortisol in humans, CORT in rodents) $(40,164)$. In rats, we refer to this period of enhanced attachment/preference learning as the "sensitive-period," or postnatal (PN) days 1-9 (see Figure 1). As we will discuss below, sensitiveperiod learning is due to the pup's unique learning circuit, presumably one sculpted through evolution to provide infants with the neural circuitry required to survive and maximize attachment to a caregiver (48).

Intriguingly, the sensitive-period for attachment learning in rat pups overlaps with the SHRP, suggesting that low levels of CORT and reduced HPA-axis responsiveness may contribute to the neonate's unique neural circuitry for attachment learning. However, in order for infant-attachment to occur, the rat pup must first learn to identify the caregiver and exhibit the social behaviors necessary for survival such as orienting to and approaching the caregiver, grasping the nipple and nursing $(50,168,169)$. Infantattachment learning in rodents revolves around the pup's ability to learn and develop a preference for the mother's odor, which is diet dependent and can change postnatally (47, 170-174). Since rat pups are born deaf and blind, they must rapidly learn their mother's odor, which conveys distal and proximal information about the mother's location, and helps the pups orient to the mother, approach her and elicit care $(169,175)$. The maternal odor is critical in guiding infant-attachment; without it, pups show reduced contact with the mother, are unable to nipple attach and exhibit low survival rates $(25,176)$. Moreover, any neutral odor can acquire properties of the natural maternal odor and act as a new maternal odor by simply being placed on the mother, in a cage during mother-infant interactions (177-182) or learned in classical conditioning paradigms (i.e., odor-stroke, odor-shock) performed outside the nest in the absence of the mother $(111,165$, 171, 183-188).

Our lab uses infant olfactory classical conditioning in which an artificial odor (i.e., peppermint) is paired with a $0.5 \mathrm{~mA}$ shock as a rodent model of abusive attachment. While the adult rat responds to shock with a robust CORT response, the neonatal rat does not $(9,100,189)$. Unlike older animals, which readily learn odor aversions to painful stimuli paired with an odor, rat pups actually exhibit an odor preference and approach the odor $(111,165,190-193)$. This odor preference, however, is not due to the inability of pups to feel pain, since the pain threshold varies little during the neonatal period and pups emit vocalizations to the shock, suggesting that they are experiencing distress $(165,190$, 194-197). Instead, infant paired-odor-shock conditioning produces a new artificial maternal odor that acquires the ability to regulate pup behaviors typically controlled by the maternal odor; it induces proximity-seeking/approach responses in pups (distal cues), guides mother-infant interactions by facilitating contact with the mother and nipple attachment (proximal cues), and activates the same neural circuitry as the natural maternal odor (25, $111,165,169)$, suggesting that this odor has comparable qualities to the natural maternal odor. Importantly, infant odor-shock conditioning is a useful experimental paradigm for understanding how early life trauma (i.e., pain-shock) can support and maintain attachment and provide insights into the particular ways the infant brain processes painful stimuli and its relationship to the enduring effects of this experience due to the well documented neural circuitry underlying this type of learning (198-202). Three brain structures have been shown to play a role in the neonatal rat's sensitive-period for enhanced odor learning: the olfactory bulb (OB), the noradrenergic locus coeruleus (LC), and the amygdala $(50,203)$.

\section{NEUROBIOLOGY OF INFANT-ATTACHMENT AND THE ROLE OF THE HPA-AXIS IN TERMINATING ATTACHMENT LEARNING}

Neonatal odor learning produces changes in the OB, which can be induced both naturally in the nest and experimentally in controlled learning experiments outside the nest (182, 186, 204-210). For example, both natural and learned odors produce a similar enhancement of $\mathrm{OB}$ responding during the sensitive-period, which has been assessed through a variety of techniques including 2-deoxy-glucose (2-DG) uptake, c-Fos immunoreactivity (ir), CREB phosphorylation, electrophysiology, and optical imaging (205-208, 211-214). Thus, olfactory-based attachment learning 
Mom: Preference/Maternal Odor Learning CORT low through social buffering LC and Olfactory Bulb

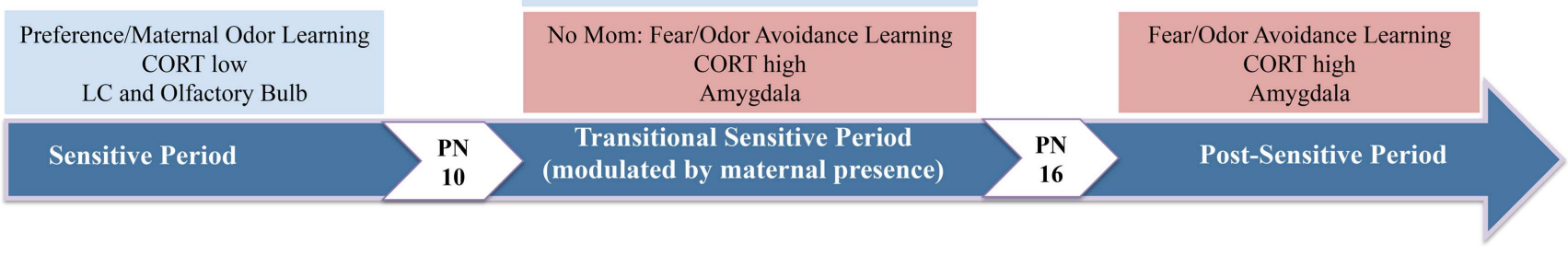

FIGURE 1 |The neural circuitry underlying pup attachment learning changes over development. During the earliest days of life, pups have a sensitive-period in which odor-shock conditioning produces an odor preference. At 10 days of age, pups begin the transitional sensitive-period, when pups endogenous CORT levels have increased sufficiently to enable amygdala-dependent fear/avoidance learning. However, with the mother present at this age, pups will revert back to preference learning and the neural circuitry of the sensitive-period. Thus, the mother's presence socially buffers pups (i.e., attenuates pups shock-induced CORT release) and pups learn a preference. As pups mature and enter the post-sensitive-period, odor-shock conditioning induces amygdala-dependent fear and odor avoidance learning $(25,165-167)$. in neonatal rats is associated with the acquisition of odor-specific neural changes in the $\mathrm{OB}$, which can only be acquired during the sensitive-period, and are retained throughout development (111, 201, 215-218).

Infant rats (PN1-9) readily learn an odor preference to neutral odors paired with pleasant (i.e., milk, stroking) $(47,171,179$, $183-185,219)$ or painful stimuli, such as $0.5 \mathrm{~mA}$ shock or tail pinch $(111,165,190,191,201)$, which is partly due to a uniquely large noradrenergic input to the $\mathrm{OB}$ from the $\mathrm{LC}$, the sole source of norepinephrine (NE) for the $\mathrm{OB}(220,221)$, which prompts abundant release of NE into the OB (203, 222). Furthermore, the neonatal LC shows prolonged stimulus-evoked excitation and greater NE release to odors during the sensitive-period compared to later-life due to the immaturity of the LC alpha-2 inhibitory autoreceptors, which functionally emerge around PN10 and cause a shift from prolonged excitatory alpha-1 mediated responses to inhibitory alpha- 2 mediated responses, resulting in brief excitation due to inhibited LC firing and decreased NE output (203, 222227). Importantly, NE release from the LC is both necessary and sufficient for odor preference learning during the sensitive-period (228-232).

Experimental evidence indicates a lack of amygdala participation in the neural circuitry underlying infant paired-odor-shock conditioning during the sensitive-period, as suggested by amygdala lesions, 2-DG, and c-Fos-ir (111, 201, 203, 216, 232), although the amygdala is strongly implicated in adult classical conditioning (198-200, 202, 233). These data suggest that the infant amygdala is not part of the sensitive-period learning circuit during which aversions are difficult to learn because of its failure to exhibit the plasticity required for this type of learning (234-236), although the amygdala is responsive to odors and other environmental stimuli by PN10 (165, 201, 237). Like the infant amygdala, the infant HPAaxis is limited in function, resulting in reduced shock-induced CORT release during the neonatal sensitive-period (189), which limits pups' ability to acquire learned odor aversions (201, 238). Endogenous CORT levels increase gradually and reach a critical level by PN10 $(92,136,239,240)$, at which time stressful or painful stimuli are able to elicit a sufficient CORT response that permits infant amygdala plasticity and avoidance learning (Figure 1) (201, $218,241)$.

Indeed, the natural increase of stress-induced CORT release marks the end of sensitive-period learning $(165,201,203,238)$, which has been demonstrated experimentally by increasing CORT systemically $(3 \mathrm{mg} / \mathrm{kg}$, i.p.) or through intra-amygdala CORT infusions (50-100 ng) prior to odor-shock conditioning, which enables sensitive-period pups to learn an odor aversion and exhibit learning-evoked neural activity (i.e., enhanced 2-DG uptake) in the amygdala, while preventing the acquisition of learninginduced changes in the $\mathrm{OB}(201,238,241,242)$. In contrast, CORT depletion (via adrenalectomy or social buffering, discussed below) in PN12 pups results in shock-induced odor preference learning and acquisition of $\mathrm{OB}$ neural changes. Thus, within the context of paired-odor-shock conditioning, CORT appears to play a modulatory role on infant learning by switching whether the amygdala learns attraction or avoidance: if CORT is low, pups learn a preference to an odor paired with shock due to a lack of amygdala involvement; if CORT is high, the amygdala is activated by odorshock conditioning and pups learn an avoidance. Recently, we have identified a role for amygdala dopamine (DA) in mediating these infant learning transitions, as conditions that block aversion/fear learning are associated with downregulated DA function (243). Altogether, these findings suggest that neonatal rat pups have unique learning capabilities that aid olfactory-based attachment to the mother, which are dependent on low levels of CORT.

In summary, the infant learning circuit is characterized by an enhanced ability to learn odor preferences to aversive stimuli, due to a hyper-functioning LC, as well as a decreased ability to learn odor aversions that may interfere with proximity-seeking during the sensitive-period due to a hypo-functional amygdala, suggesting that the infant brain is specialized for maximizing attachment to a caregiver (Figure 1) $(41,165,186,221,225,229,234,235,244-$ 247). As the sensitive-period ends, owing to the natural emergence of CORT, odor aversions can be learned because of changes in the infant learning circuit, including maturation of LC autoinhibition, which reduces NE release and greatly attenuates rapid odor preference learning, but also due to the functional emergence of the 
amygdala, all of which enable the plasticity required for aversion learning $(50,165,223,225,229,232,241)$.

\section{MATERNAL MODULATION OF HPA-AXIS FUNCTION AND SENSITIVE-PERIOD DURATION}

Empirical evidence suggests that social support is a powerful modulator of individual differences in response to potentially stressful events in both humans and animals (248-253). In rodents, maternal presence is known to blunt CORT release to stressful and painful stimuli in older pups ( $>$ PN12) through olfactory and somatosensory cues $(9,148,152,166,167,254,255)$. The process by which the presence of a social companion and/or social sensory cues can dampen HPA responses to stressors (i.e., decrease CORT levels) is termed "social buffering" and has been reported in humans and other species $(139,249,250,253,256-259)$. Our lab has identified a transitional sensitive-period in pups from PN1015 , during which odor-shock conditioning produces either olfactory preference or aversion in infant rats depending on social context $(166,260)$. In the absence of the mother, paired-odor-shock conditioning yields a learned odor avoidance that is accompanied by amygdala activation. However, maternal presence is able to suppress amygdala activity and block aversion learning induced by odor-shock conditioning, indicating that maternal presence reengages the sensitive-period attachment circuitry to reinstate odor preference learning through modulation of CORT (see Figure 1), and therefore CORT regulation of amygdala activity. Importantly, these animal data are consistent with the principles of attachment theory (38), in which access to a secure base provided by the attachment figure reduces the probability of HPA/CRF stress reactions that could have unfavorable long-term consequences on brain development $(9,137,261)$.

Yet, human parental care is disturbed under conditions of chronic stress (262), which can be modeled in rodents by creating an abnormal rearing environment that alters maternal behavior $(20,23,111)$ and mimics the effects of a stressful environment as a risk factor for potentiating infant abuse, including humans $(62,77$, $263,264)$. Because bedding type and volume are important components of the dam's nesting environment, limiting the amount of bedding available constitutes a continuous stressor for the dam and her pups, disrupts mother-pup interactions, and alters the development of the pup's HPA-axis by reducing the frequency of positive maternal behaviors (i.e., licking, grooming, nursing) and increasing the frequency of negative maternal behaviors that are painful to the pup and elicit vocalizations, such as stepping, dragging, and rough handling of the pups $(20,25,111,156,188,265)$. Thus, one could conceptualize a stressed dam as a poor regulator, which is supported by findings showing that ICV infusion of corticotropin releasing factor (CRF) reduces maternal responsivity (266).

Furthermore, because maternal stimulation of pups modulates pups' endogenous CORT, maternal care quality alters sensitiveperiod duration. Pups reared with a stressed mother (i.e., poor regulator) exhibit a precocious emergence of CORT, which is delivered through the mother's milk (267), that facilitates aversion learning and engages the amygdala, as indexed by increased odor-shock-induced amygdala neural activity (188), suggesting that experience with a stressed mother prematurely ends the SHRP and the sensitive-period for attachment learning. In addition, this procedure results in striking changes in the expression and activity patterns of key regulatory elements of the neuroendocrine stress response, which result in persistent alterations of HPA-axis function such as elevated basal GC concentrations, impaired GC feedback, and modifications in CRF-receptor regulation (20, 25, $114,156,174)$. Since the mother serves as a primary link between the environment and the infant, environmentally driven alterations in maternal care could transduce an environmental signal to the pups, alter the development of central CRF systems activating behavioral, endocrine and autonomic responses to stress, as well as systems regulating CRF and HPA-axis activity, which may serve to increase or decrease stress-reactivity in the offspring, so that it mirrors that of the mother.

\section{IMMEDIATE AND ENDURING EFFECTS OF EARLY LIFE STRESS}

Responses to stressors, or conditions that threaten or are perceived to threaten physiological equilibrium, are mediated by the activation of stress-responsive neurobiological systems that help preserve allostasis, or stability through change, thereby making the stress response an essential endocrine mechanism for survival (268-270). Stressors, which can include psychological and physical challenges, increase the amount of hypothalamic CRF that is released into the anterior pituitary gland, stimulating ACTH secretion in the anterior pituitary and resulting in GC production in the adrenal gland $(268,271,272)$. GCs facilitate the mobilization of substrates for energy sources, potentiate the release of catecholamines, and enhance cardiovascular tone while suppressing "non-essential systems" for immediate survival, such as immunity, growth, and reproduction (273-276). Stress-induced HPAaxis activation is associated with acute release of stress-related neuropeptides, hormones, and neurotransmitters, including NE, serotonin (5-HT), and DA, in cortical and limbic structures (21, 27, 277-289). Although acutely elevated GCs help orchestrate physiological and behavioral responses that promote allostasis, chronic activation of the HPA-axis, and prolonged elevations of GCs and CRF increase the risk of stress-related disorders and psychological illnesses during later-life (269, 290-292).

The effects of HPA-axis activation depend on multiple factors, including the developmental stage in which the insult occurs, number of exposures, and type of adversity (71, 293-297). Numerous behavioral, endocrine, and clinical studies have shown that various early life stressors cause a premature increase in CORT levels (129) that produces profound alterations in growth and development and negatively affects mental health $(40,72,135,298,299)$. Moreover, repeated exposure to early life stressors, both physical and psychological, induce changes in endocrine (HPA-axis), neurotransmitter (DA, 5-HT), and brain memory systems, including the hippocampus, amygdala, and PFC that persist throughout the life-span $(8,67,101,300,301)$. Furthermore, the HPA-axis is modulated by limbic and cortical regions such as the amygdala, hippocampus, and the PFC $(269,302)$, which enable the activation of stress responses by psychosocial stressors (303-307). Importantly, the timing of early life stress may affect brain regions undergoing specific growth spurts during that time $(308,309)$, so that brain regions rich in $\mathrm{GC}$ receptors and characterized by extended $\mathrm{PN}$ development, such as the amygdala, hippocampus, and PFC, are 
particularly susceptible to the long-term effects of stress $(71,92)$, which affects later-life memory, cognitive, executive, and affective function as well as stress-reactivity in humans (296, 297). Alterations in stress-sensitive neurobiological systems, including regulation of GCs and CRF, have been posited as mechanisms through which early life stress, including inadequate/disorganized parental care, increases the likelihood of psychopathology by influencing HPA hyperreactivity to stressors and promoting the development of stress-induced illnesses throughout life (31, 40, 290, 310-312).

Early life adversity may lead to a maladaptive outcome to a given later environmental context. Depression is a common outcome of childhood abuse, and children with a comorbid history of depression and abuse have elevated CRF levels in the cerebrospinal fluid (313) as well as an increased ACTH response to a CRF challenge compared to children with depression without abuse, suggesting excessive CRF release (3, 314, 315). Additional clinical evidence indicates that severe early life stressors in childhood are associated with the long-term HPA-axis disturbances in depressed patients (316-319), which is supported by preclinical studies of non-human primates showing that poor rearing conditions and conditions that disrupt responsive maternal care have a long-term impact on the neurobiology of stress and negative emotionality $(21,31,32,109,158)$. For example, variable foraging paradigms that result in neglectful maternal care produce adult offspring that are more fearful, low in dominance, have elevated levels of CRF in the CSF and high in brain levels of CRH, exhibit persistent alterations in metabolites of 5-HT, DA, and NE, as well as changes in noradrenergic and serotonergic responses to stress (99, 320-324). Given the importance of noradrenergic and serotonergic systems in mood disorders, these findings postulate a mechanism by which early life stress may predispose an individual to later-life depression $(32,300,325-327)$.

\section{CONVERGENCE OF BOTH ABUSIVE ATTACHMENT MODELS IN PRODUCING A DEPRESSIVE-LIKE BEHAVIORAL PHENOTYPE DURING LATER-LIFE}

Recently, our lab has demonstrated that both rodent models of abusive attachment (paired-odor-shock, abusive mother) during infancy result in later-life depressive-like behavior in the Forced Swim Test (FST), a measure of behavioral despair in rodents (328, $329)$, that is accompanied by changes in amygdala function and preceded by disruptions in social behavior (26). When employed from PN8-12, these two complementary rodent models of early life abuse produced a reduction in sociability, as indexed by spending significantly less time in a social chamber compared to control animals reared with a normal mother - a behavioral pattern that was observable prior to weaning (PN23) and maintained in adolescence (PN45). However, animals experiencing early life abuse only showed depressive-like behavior in the FST during adolescence (PN45), as indicated by immobility - the passive state in which the animal makes only those movements necessary to keep its head above water $(328,330)$. In addition, depressive-like behavior in the FST in animals experiencing early life abuse was associated with increased c-Fos-ir in the basal, lateral, and central amygdala nuclei, suggesting that increased neural activity in these structures may contribute to the expression of depressive-like behavior in the FST (26). A causal relationship between amygdala function and depressive-like behavior in the FST was suggested through temporary inactivation (i.e., muscimol) of amygdala function during the FST, which normalized these behaviors to a level comparable to controls (26). Collectively, these findings suggest that the expression of depressive-like behavior in the FST following early life abuse is characterized by a hyper-functioning amygdala. Thus, abusive attachment appears to disrupt the developmental trajectory of the amygdala and modify the way that it responds to future stressors, which is supported by our work using rodent models of early life abuse.

Our findings are in accordance with clinical and animal literature indicating that early life adversity constitutes a prime risk factor for the development of psychopathologies characterized by dysregulated HPA-axis function (1, 5, 24, 32, 133, 319, 331-334), such as mood and affective disorders $(37,93,335,336)$, which also exhibit a developmental delay $(309,337,338)$ Thus, these rodent models of early life abuse allow us to explore the ontogeny of depressive-like behavior and amygdala dysregulation, which is of clinical relevance because abnormal amygdala function and social behavior deficits as well as their relationship to later-life depressive-like behaviors have been documented in individuals with a history of early life abuse $(71,310,331,336)$.

\section{MODULATION OF ADULT NEUROBEHAVIORAL FUNCTION BY INFANT-ATTACHMENT RELATED CUES}

An ample body of evidence suggests that the quality of infantattachment relationships results in long-term adaptations that have the ability to program subsequent behavioral, endocrine, and neural function $(28,109,261,310,336)$. Results from our laboratory have shown that infant paired-odor-shock conditioning results in reduced fear learning and attenuated related amygdala function, dysregulation in neural networks underlying olfactory learning, and depressive-like behavior during adulthood (339342). Importantly, attachment related sensory cues learned during infancy can play a critical role in modulating neurobehavioral responses during later-life. In humans, for example, cues associated with early life abuse elicit strong attraction and feelings of comfort (343). In rodents, presentation of an artificial maternal odor, resulting from infant paired-odor-shock conditioning, is able to reverse the behavioral effects of abusive attachment in rodent measures of depressive-like behavior, such as the sucrose consumption test and the FST (342). Specifically, the odor increased the latency to immobility and reduced the time spent immobile in the FST, but also increased the percentage of sucrose consumed during a sucrose preference test to levels comparable to controls. Furthermore, these restorative effects of a learned infant maternal odor on adult function were also observable at electrophysiological level, as odor presentation also normalized paired-pulse inhibition deficits in the amygdala. Collectively, these data suggest that early life experiences are able to shape adult neural circuits underlying behavior and that adult behaviors can be modified under environmental conditions in which learned infant cues are present. The discovery that infant cues can retain their value throughout the life-span and regulate later-life behaviors controlled by circuits implicated in emotion, learning, and social behavior is of great interest because it provides an opportunity for intervention and possibly correction of maladaptive outcomes related to psychopathology induced by adverse early life experiences within attachment. Thus, it appears that the enduring neurobehavioral 
dysregulation stemming from early life abuse can be positively modulated by learned sensory cues related to infant-attachment.

\section{CONCLUSION}

In species requiring parental care, evolution has ensured that infants quickly learn and express robust preferences to the caregiver, regardless of the quality of care $(48,50)$. However, trauma within attachment leaves the infant particularly vulnerable to adult psychiatric disorders, behavioral changes in fear and anxiety, and alterations in neural circuits, particularly those regulating stress and emotion $(71,133,334,344,345)$. In addition, early life stress can have negative effects on the neurobiology of the developing brain that are comparable to those induced by disruptions in infant-caregiver interactions $(25,346)$ Thus, early life experiences have enduring effects on the neuroplasticity of the HPA-axis, suggesting the HPA-axis is programmable via multiple environmental sources across development. In early development, stressors and maternal care jointly program HPA-axis responses and later-life function. The HPA-axis, however, remains modifiable during later stages of development during which infant-attachment related cues can exert a positive modulatory effect on later-life HPA-axis function as well as behavioral and endocrine responses to stress.

\section{ACKNOWLEDGMENTS}

This work was supported by the National Science Foundation Graduate Research Fellowship (DGE-1137475) to Millie Rincón-Cortés and NIH-MH091451, NIH-DC009910 to Regina M. Sullivan.

\section{REFERENCES}

1. Anisman H, Zaharia MD, Meaney MJ, Merali Z. Do early-life events permanently alter behavioral and hormonal responses to stressors? Int J Dev Neurosci (1998) 16:149-64. doi:10.1016/S0736-5748(98)00025-2

2. Meaney MJ, Szyf M. Environmental programming of stress responses through DNA methylation: life at the interface between a dynamic environment and a fixed genome. Dialogues Clin Neurosci (2005) 7:103-23.

3. Romeo RD, Tang AC, Sullivan RM. Early life experiences: enduring behavioral, neurological and endocrinological consequences. In: Anne DWP, Etgen M, editors. Molecular Mechanisms of Hormone Actions on Behavior. San Diego, CA: Academic Press (2009). p. 543-72.

4. Bale TL, Baram TZ, Brown AS, Goldstein JM, Insel TR, McCarthy MM, et al. Early life programming and neurodevelopmental disorders. Biol Psychiatry (2010) 68:314-9. doi:10.1016/jbiopsych.2010.05.028

5. Grace CE, Kim SJ, Rogers JM. Maternal influences on epigenetic programming of the developing hypothalamic-pituitary-adrenal axis. Birth Defects Res A Clin Mol Teratol (2011) 91:797-805. doi:10.1002/bdra.20824

6. Levine S. Maternal and environmental influences on the adrenocortical response to stress in weanling rats. Science (1967) 156:258-60. doi:10.1126/ science.156.3772.258

7. Liu D, Diorio J, Tannenbaum B, Caldji C, Francis D, Freedman A, et al. Maternal care, hippocampal glucocorticoid receptors, and hypothalamic-pituitaryadrenal responses to stress. Science (1997) 277:1659-62. doi:10.1126/science. 277.5332.1659

8. Francis DD, Meaney MJ. Maternal care and the development of stress responses. Curr Opin Neurobiol (1999) 9:128-34. doi:10.1016/S0959-4388(99)80016-6

9. Levine S. Primary social relationships influence the development of the hypothalamic - pituitary - adrenal axis in the rat. Physiol Behav (2001) 73:255-60. doi:10.1016/S0031-9384(01)00496-6

10. Walker CD. Maternal touch and feed as critical regulators of behavioral and stress responses in the offspring. Dev Psychobiol (2010) 52:638-50. doi:10.1002/dev.20492
11. Hofer MA. Hidden regulatory processes in early social relationships. In: Klopfer PH, editor. Perspectives in Ethology: Social Behavior. New York, NY: Plenum Press (1978). p. 135-66.

12. Hofer MA. Hidden regulators in attachment, separation, and loss. Monogr Soc Res Child Dev (1994) 59:192-207. doi:10.2307/1166146

13. Dettling AC, Feldon J, Pryce CR. Repeated parental deprivation in the infant common marmoset (Callithrix jacchus, primates) and analysis of its effects on early development. Biol Psychiatry (2002) 52:1037-46. doi:10.1016/S00063223(02)01460-9

14. Levine S. Developmental determinants of sensitivity and resistance to stress. Psychoneuroendocrinology (2005) 30:939-46. doi:10.1016/j.psyneuen. 2005.03.013

15. Stanton ME, Gutierrez YR, Levine S. Maternal deprivation potentiates pituitary-adrenal stress responses in infant rats. Behav Neurosci (1988) 102:692-700. doi:10.1037/0735-7044.102.5.692

16. Kuhn CM, Pauk J, Schanberg SM. Endocrine responses to mother-infant separation in developing rats. Dev Psychobiol (1990) 23:395-410. doi:10.1002/dev. 420230503

17. Levine S, Huchton DM, Wiener SG, Rosenfeld P. Time course of the effect of maternal deprivation on the hypothalamic-pituitary-adrenal axis in the infant rat. Dev Psychobiol (1991) 24:547-58. doi:10.1002/dev.420240803

18. Rosenfeld P, Suchecki D, Levine S. Multifactorial regulation of the hypothalamic-pituitary-adrenal axis during development. Neurosci Biobehav Rev (1992) 16:553-68. doi:10.1016/S0149-7634(05)80196-4

19. Avishai-Eliner S, Yi SJ, Newth CJ, Baram TZ. Effects of maternal and sibling deprivation on basal and stress induced hypothalamic-pituitary-adrenal components in the infant rat. Neurosci Lett (1995) 192:49-52. doi:10.1016/03043940(95)11606-W

20. Gilles EE, Schultz L, Baram TZ. Abnormal corticosterone regulation in an immature rat model of continuous chronic stress. Pediatr Neurol (1996) 15:114-9. doi:10.1016/0887-8994(96)00153-1

21. Ladd CO, Owens MJ, Nemeroff CB. Persistent changes in corticotropinreleasing factor neuronal systems induced by maternal deprivation. Endocrinology (1996) 137:1212-8. doi:10.1210/endo.137.4.8625891

22. Cirulli F, Berry A, Alleva E. Early disruption of the mother-infant relationship: effects on brain plasticity and implications for psychopathology. Neurosci Biobehav Rev (2003) 27:73-82. doi:10.1016/S0149-7634(03)00010-1

23. Ivy AS, Brunson KL, Sandman C, Baram TZ. Dysfunctional nurturing behavior in rat dams with limited access to nesting material: a clinically relevant model for early-life stress. Neuroscience (2008) 154:1132-42. doi:10.1016/j. neuroscience.2008.04.019

24. McEwen BS. Understanding the potency of stressful early life experiences on brain and body function. Metabolism (2008) 57(Suppl 2):S11-5. doi:10.1016/ j.metabol.2008.07.006

25. Raineki C, Moriceau S, Sullivan RM. Developing a neurobehavioral animal model of infant attachment to an abusive caregiver. Biol Psychiatry (2010) 67:1137-45. doi:10.1016/j.biopsych.2009.12.019

26. Raineki C, Cortes MR, Belnoue L, Sullivan RM. Effects of early-life abuse differ across development: infant social behavior deficits are followed by adolescent depressive-like behaviors mediated by the amygdala. J Neurosci (2012) 32:7758-65. doi:10.1523/JNEUROSCI.5843-11.2012

27. Plotsky PM, Meaney MJ. Early, postnatal experience alters hypothalamic corticotropin-releasing factor (CRF) mRNA, median eminence CRF content and stress-induced release in adult rats. Brain Res Mol Brain Res (1993) 18:195-200. doi:10.1016/0169-328X(93)90189-V

28. Canetti L, Bachar E, Galili-Weisstub E, De-Nour AK, Shalev AY. Parental bonding and mental health in adolescence. Adolescence (1997) 32:381-94.

29. Caldji C, Tannenbaum B, Sharma S, Francis D, Plotsky PM, Meaney MJ. Maternal care during infancy regulates the development of neural systems mediating the expression of fearfulness in the rat. Proc Natl Acad Sci U S A (1998) 95:5335-40. doi:10.1073/pnas.95.9.5335

30. Caldji C, Diorio J, Meaney MJ. Variations in maternal care in infancy regulate the development of stress reactivity. Biol Psychiatry (2000) 48:1164-74. doi:10.1016/S0006-3223(00)01084-2

31. Heim C, Nemeroff CB. The role of childhood trauma in the neurobiology of mood and anxiety disorders: preclinical and clinical studies. Biol Psychiatry (2001) 49:1023-39. doi:10.1016/S0006-3223(01)01157-X 
32. Sanchez MM, Ladd CO, Plotsky PM. Early adverse experience as a developmental risk factor for later psychopathology: evidence from rodent and primate models. Dev Psychopathol (2001) 13:419-49. doi:10.1017/S0954579401003029

33. De Bellis MD. The psychobiology of neglect. Child Maltreat (2005) 10:150-72. doi:10.1177/1077559505275116

34. Hane AA, Fox NA. Ordinary variations in maternal caregiving influence human infants' stress reactivity. Psychol Sci (2006) 17:550-6. doi:10.1111/j.1467-9280. 2006.01742.x

35. Zhang TY, Bagot R, Parent C, Nesbitt C, Bredy TW, Caldji C, et al. Maternal programming of defensive responses through sustained effects on gene expression. Biol Psychol (2006) 73:72-89. doi:10.1016/j.biopsycho.2006.01.009

36. Neigh GN, Gillespie CF, Nemeroff CB. The neurobiological toll of child abuse and neglect. Trauma Violence Abuse (2009) 10:389-410. doi:10.1177/ 1524838009339758

37. Gershon A, Sudheimer K, Tirouvanziam R, Williams LM, O’Hara R. The longterm impact of early adversity on late-life psychiatric disorders. Curr Psychiatry Rep (2013) 15:352. doi:10.1007/s11920-013-0352-9

38. Bowlby J. Attachment. Attachment and Loss: Vol. I. Loss. New York, NY: Basic Books (1969).

39. Ainsworth MDS. The development of infant-mother attachment. In: Ricciuti $\mathrm{BCH}$, editor. Review of Child Developmental Research. Chicago: University of Chicago Press (1973). p. 1-94.

40. Gunnar M, Quevedo K. The neurobiology of stress and development. Annu Rev Psychol (2007) 58:145-73. doi:10.1146/annurev.psych.58.110405.085605

41. Hess E. Ethology: an approach to the complete analysis of behavior. In: Brown EGR, Hess E, Mendler G, editors. New Directions in Psychology. New York, NY: Holt, Rineheart and Winston (1962). p. 159-99.

42. Ainsworth MDS. Object relations, dependency, and attachment: a theoretical review of the infant-mother relationship. Child Dev (1969) 40:969-1025. doi:10.2307/1127008

43. Rajecki DWL, Michael E, Obmascher P. Toward a general theory of infantile attachment: a comparative review of aspects of the social bond. Behav Brain Sci (1978) 1:417-64. doi:10.1017/S0140525X00075816

44. DeCasper AJ, Fifer WP. Of human bonding: newborns prefer their mothers' voices. Science (1980) 208:1174-6. doi:10.1126/science.7375928

45. Hennessy MB, Li J, Levine S. Infant responsiveness to maternal cues in mice of 2 inbred lines. Dev Psychobiol (1980) 13:77-84. doi:10.1002/dev.420130111

46. Gewirtz SBP. The attachment learning process and its relation to cultural and biological evolution: proximate and ultimate considerations. In: Field MRAT, editor. The Psychobiology of Attachment and Separation. Orlando, FL: Academic Press Inc (1985). p. 259-86.

47. Polan HJ, Hofer MA. Olfactory preference for mother over home nest shavings by newborn rats. Dev Psychobiol (1998) 33:5-20. doi:10.1002/(SICI)10982302(199807)33:1<5::AID-DEV2>3.0.CO;2-P

48. Hofer MA, Sullivan RM. Towards a neurobiology of attachment. In: Nelson CA, editor. Developmental Cognitive Neuroscience. Cambridge: MIT Press (2001). p. 599-616.

49. Bowlby J. The nature of the child's tie to his mother. Int J Psychoanal (1958) 39:350-73.

50. Sullivan RM. Developing a sense of safety: the neurobiology of neonatal attachment. Ann N Y Acad Sci (2003) 1008:122-31. doi:10.1196/annals.1301.013

51. Sullivan R, Perry R, Sloan A, Kleinhaus K, Burtchen N. Infant bonding and attachment to the caregiver: insights from basic and clinical science. Clin Perinatol (2011) 38:643-55. doi:10.1016/j.clp.2011.08.011

52. Ainsworth MS. Infant - mother attachment. Am Psychol (1979) 34:932-7. doi:10.1037/0003-066X.34.10.932

53. Ainsworth MDS. Patterns of infant-mother attachments: antecedents and effects on development. Bull N Y Acad Med (1985) 61:771-91.

54. Bowlby J. Attachment: Attachment and Loss. New York, NY: Basic Books (1982). 55. Bowlby J. Attachment. New York, NY: Basic Books (1965).

56. Fisher AE. The Effects of Differential Early Treatment on the Social and Exploratory Behavior in Puppies. Ph.D. thesis. University Park (PA): Pennsylvania State University (1955).

57. Stanley W. Differential human handling as reinforcing events and as treatments influencing later social behavior in basenji puppies. Psychol Rep (1962) 10:775-88. doi:10.2466/pr0.1962.10.3.775

58. Harlow HF, Harlow MK. The affectional systems. In: Schrier HF, Stollnitz F, editors. Behavior of Nonhuman Primates. New York, NY: Academic Press (1965). p. 287-344.
59. Salzen EA. Imprinting and environmental learning. In: Aronson LR, Lehrman DS, Rosenblatt J, editors. Development and Evolution of Behavior. San Francisco, CA: W.H. Freeman (1970). p. 158-78.

60. Helfer ME, Kempe RS, Krugman RD. The Battered Child. Chicago, IL: University Press (1997).

61. Carroll KA, Maestripieri D. Infant abuse and neglect in monkeys - a discussion of definitions, epidemiology, etiology, and implications for child maltreatment: reply to Cicchetti (1998) and Mason (1998). Psychol Bull (1998) 123:234-7. doi:10.1037/0033-2909.123.3.234

62. Maestripieri D, Carroll KA. Child abuse and neglect: usefulness of the animal data. Psychol Bull (1998) 123:211-23. doi:10.1037/0033-2909.123.3.211

63. Hofer MA, Sullivan RM. Toward a neurobiology of attachment. In: Nelson CA, Luciana M, editors. Handbook of Developmental Cognitive Neuroscience. Cambridge: MIT Press (2008). p. 787-806.

64. Sapolsky R. Any kind of mother in a storm. Nat Neurosci (2009) 12:1355-6. doi:10.1038/nn1109-1355

65. Joseph R. Environmental influences on neural plasticity, the limbic system, emotional development and attachment: a review. Child Psychiatry Hum Dev (1999) 29:189-208. doi:10.1023/A:1022660923605

66. Glaser D. Child abuse and neglect and the brain - a review. J Child Psychol Psychiatry (2000) 41:97-116. doi:10.1017/S0021963099004990

67. Bremner JD, Vermetten E. Stress and development: behavioral and biological consequences. Dev Psychopathol (2001) 13:473-89. doi:10.1017/ S0954579401003042

68. Dent GW, Smith MA, Levine S. Stress-induced alterations in locus coeruleus gene expression during ontogeny. Brain Res Dev Brain Res (2001) 127:23-30. doi:10.1016/S0165-3806(01)00108-0

69. Vythilingam M, Heim C, Newport J, Miller AH, Anderson E, Bronen R, et al. Childhood trauma associated with smaller hippocampal volume in women with major depression. Am J Psychiatry (2002) 159:2072-80. doi:10.1176/appi. ajp.159.12.2072

70. Bremner JD. Long-term effects of childhood abuse on brain and neurobiology. Child Adolesc Psychiatr Clin N Am (2003) 12:271-92. doi:10.1016/S10564993(02)00098-6

71. Teicher MH, Andersen SL, Polcari A, Anderson CM, Navalta CP, Kim DM. The neurobiological consequences of early stress and childhood maltreatment. Neurosci Biobehav Rev (2003) 27:33-44. doi:10.1016/S0149-7634(03) 00007-1

72. Cirulli F, Francia N, Berry A, Aloe L, Alleva E, Suomi SJ. Early life stress as a risk factor for mental health: role of neurotrophins from rodents to non-human primates. Neurosci Biobehav Rev (2009) 33:573-85. doi:10.1016/j.neubiorev. 2008.09.001

73. Braun K, Bock J. The experience-dependent maturation of prefrontolimbic circuits and the origin of developmental psychopathology: implications for the pathogenesis and therapy of behavioural disorders. Dev Med Child Neurol (2011) 53(Suppl 4):14-8. doi:10.1111/j.1469-8749.2011. 04056.x

74. Blaze J, Scheuing L, Roth TL. Differential methylation of genes in the medial prefrontal cortex of developing and adult rats following exposure to maltreatment or nurturing care during infancy. Dev Neurosci (2013) 35:306-16. doi:10.1016/j.ijdevneu.2013.10.001

75. Gee DG, Gabard-Durnam LJ, Flannery J, Goff B, Humphreys KL, Telzer EH, et al. Early developmental emergence of human amygdala-prefrontal connectivity after maternal deprivation. Proc Natl Acad Sci US A (2013) 110:15638-43. doi:10.1073/pnas.1307893110

76. Rutter M. The long-term effects of early experience. Dev Med Child Neurol (1980) 22:800-15. doi:10.1111/j.1469-8749.1980.tb03751.x

77. Cicchetti D. How research on child maltreatment has informed the study of child development: perspectives from development psychopathology. In: Cicchetti D, Carlson V, editors. Child Maltreatment: Theory and Research on the Causes and Consequences of Child Abuse and Neglect. New York, NY: Cambridge University Press (1990). p. 377-431.

78. Shields AM, Cicchetti D, Ryan RM. The development of emotional and behavioral self-regulation and social competence among maltreated school-age children. Dev Psychopathol (1994) 6:57-75. doi:10.1017/ S0954579400005885

79. Cicchetti D, Toth SL. A developmental psychopathology perspective on child abuse and neglect. J Am Acad Child Adolesc Psychiatry (1995) 34:541-65. doi:10.1097/00004583-199505000-00008 
80. Rutter M. Developmental catch-up, and deficit, following adoption after severe global early privation. English and Romanian Adoptees (ERA) Study Team. J Child Psychol Psychiatry (1998) 39:465-76. doi:10.1017/S0021963098002236

81. O'Connor TG, Rutter M. Attachment disorder behavior following early severe deprivation: extension and longitudinal follow-up. English and Romanian Adoptees Study Team. J Am Acad Child Adolesc Psychiatry (2000) 39:703-12. doi:10.1097/00004583-200006000-00008

82. De Bellis MD. Developmental traumatology: the psychobiological development of maltreated children and its implications for research, treatment, and policy. Dev Psychopathol (2001) 13:539-64. doi:10.1017/S0954579401003078

83. Schore AN. Dysregulation of the right brain: a fundamental mechanism of traumatic attachment and the psychopathogenesis of posttraumatic stress disorder. Aust N Z J Psychiatry (2002) 36:9-30. doi:10.1046/j.1440-1614.2002.00996.x

84. Nemeroff CB. Neurobiological consequences of childhood trauma. J Clin Psychiatry (2004) 65(Suppl 1):18-28.

85. Rogosch FA, Cicchetti D. Child maltreatment, attention networks, and potential precursors to borderline personality disorder. Dev Psychopathol (2005) 17:1071-89. doi:10.1017/S0954579405050509

86. Anda RF, Felitti VJ, Bremner JD, Walker JD, Whitfield C, Perry BD, et al. The enduring effects of abuse and related adverse experiences in childhood. A convergence of evidence from neurobiology and epidemiology. Eur Arch Psychiatry Clin Neurosci (2006) 256:174-86. doi:10.1007/s00406-005-0624-4

87. Barber-Madden R, Cohn AH, Schloesser P. Prevention of child abuse: a public health agenda. J Public Health Policy (1988) 9:167-76. doi:10.2307/3343003

88. Barnett D, Manly JT, Cicchetti D. Defining child maltreatment: the interface between policy and research. In: Toth DCSL, editor. Child Abuse, Child Development, and Social Policy. Norwood, NJ: Ablex (1993). p. 7-72.

89. Merrick J, Browne KD. Child abuse and neglect - a public health concern. Public Health Rev (1999) 27:279-93.

90. Dawson G, Ashman SB, Carver LJ. The role of early experience in shaping behavioral and brain development and its implications for social policy. Dev Psychopathol (2000) 12:695-712. doi:10.1017/S0954579400004089

91. Kendall-Tackett K. The health effects of childhood abuse: four pathways by which abuse can influence health. Child Abuse Negl (2002) 26:715-29. doi:10.1016/S0145-2134(02)00343-5

92. De Kloet ER, Rosenfeld P, Van Eekelen JA, Sutanto W, Levine S. Stress, glucocorticoids and development. Prog Brain Res (1988) 73:101-20. doi:10.1016/ S0079-6123(08)60500-2

93. Heim C, Plotsky PM, Nemeroff CB. Importance of studying the contributions of early adverse experience to neurobiological findings in depression. Neuropsychopharmacology (2004) 29:641-8. doi:10.1038/sj.npp.1300397

94. Kaufman J, Plotsky PM, Nemeroff CB, Charney DS. Effects of early adverse experiences on brain structure and function: clinical implications. Biol Psychiatry (2000) 48:778-90. doi:10.1016/S0006-3223(00)00998-7

95. Stevens HE, Leckman JF, Coplan JD, Suomi SJ. Risk and resilience: early manipulation of macaque social experience and persistent behavioral and neurophysiological outcomes. J Am Acad Child Adolesc Psychiatry (2009) 48:114-27. doi:10.1097/CHI.0b013e318193064c

96. Korosi A, Baram TZ. Plasticity of the stress response early in life: mechanisms and significance. Dev Psychobiol (2010) 52:661-70. doi:10.1002/dev.20490

97. Lyons DM, Parker KJ, Schatzberg AF. Animal models of early life stress: implications for understanding resilience. Dev Psychobiol (2010) 52:402-10. doi:10.1002/dev.20429

98. Franklin TB, Saab BJ, Mansuy IM. Neural mechanisms of stress resilience and vulnerability. Neuron (2012) 75:747-61. doi:10.1016/j.neuron.2012.08.016

99. Rosenblum LA, Coplan JD, Friedman S, Bassoff T, Gorman JM, Andrews MW. Adverse early experiences affect noradrenergic and serotonergic functioning in adult primates. Biol Psychiatry (1994) 35:221-7. doi:10.1016/0006-3223(94) 91252-1

100. van Oers HJ, De Kloet ER, Whelan T, Levine S. Maternal deprivation effect on the infant's neural stress markers is reversed by tactile stimulation and feeding but not by suppressing corticosterone. J Neurosci (1998) 18:10171-9.

101. Andersen SL, Lyss PJ, Dumont NL, Teicher MH. Enduring neurochemical effects of early maternal separation on limbic structures. Ann N Y Acad Sci (1999) 877:756-9. doi:10.1111/j.1749-6632.1999.tb09317.x

102. Huot RL, Plotsky PM, Lenox RH, McNamara RK. Neonatal maternal separation reduces hippocampal mossy fiber density in adult Long Evans rats. Brain Res (2002) 950:52-63. doi:10.1016/S0006-8993(02)02985-2
103. Brake WG, Zhang TY, Diorio J, Meaney MJ, Gratton A. Influence of early postnatal rearing conditions on mesocorticolimbic dopamine and behavioural responses to psychostimulants and stressors in adult rats. Eur J Neurosci (2004) 19:1863-74. doi:10.1111/j.1460-9568.2004.03286.x

104. Pryce CR, Dettling AC, Spengler M, Schnell CR, Feldon J. Deprivation of parenting disrupts development of homeostatic and reward systems in marmoset monkey offspring. Biol Psychiatry (2004) 56:72-9. doi:10.1016/j.biopsych. 2004.05.002

105. Tottenham N, Hare TA, Quinn BT, McCarry TW, Nurse M, Gilhooly T, et al. Prolonged institutional rearing is associated with atypically large amygdala volume and difficulties in emotion regulation. Dev Sci (2010) 13:46-61. doi:10.1111/j.1467-7687.2009.00852.x

106. Hostinar CE, Stellern SA, Schaefer C, Carlson SM, Gunnar MR. Associations between early life adversity and executive function in children adopted internationally from orphanages. Proc Natl Acad Sci U S A (2012) 109(Suppl 2):17208-12. doi:10.1073/pnas.1121246109

107. Tottenham N. Human amygdala development in the absence of speciesexpected caregiving. Dev Psychobiol (2012) 54:598-611. doi:10.3389/neuro.09. 068.2009

108. Malter Cohen M, Jing D, Yang RR, Tottenham N, Lee FS, Casey BJ. Early-life stress has persistent effects on amygdala function and development in mice and humans. Proc Natl Acad Sci U S A (2013) 110:18274-8. doi:10.1073/pnas. 1310163110

109. Ladd CO, Huot RL, Thrivikraman KV, Nemeroff CB, Meaney MJ, Plotsky PM. Long-term behavioral and neuroendocrine adaptations to adverse early experience. Prog Brain Res (2000) 122:81-103. doi:10.1016/S0079-6123(08)62132-9

110. Liu D, Caldji C, Sharma S, Plotsky PM, Meaney MJ. Influence of neonatal rearing conditions on stress-induced adrenocorticotropin responses and norepinephrine release in the hypothalamic paraventricular nucleus. J Neuroendocrinol (2000) 12:5-12. doi:10.1046/j.1365-2826.2000.00422.x

111. Roth TL, Sullivan RM. Memory of early maltreatment: neonatal behavioral and neural correlates of maternal maltreatment within the context of classical conditioning. Biol Psychiatry (2005) 57:823-31. doi:10.1016/j.biopsych.2005. 01.032

112. Fenoglio KA, Chen Y, Baram TZ. Neuroplasticity of the hypothalamicpituitary-adrenal axis early in life requires recurrent recruitment of stress-regulating brain regions. J Neurosci (2006) 26:2434-42. doi:10.1523/ JNEUROSCI.4080-05.2006

113. Branchi I, D’Andrea I, Cirulli F, Lipp HP, Alleva E. Shaping brain development: mouse communal nesting blunts adult neuroendocrine and behavioral response to social stress and modifies chronic antidepressant treatment outcome. Psychoneuroendocrinology (2010) 35:743-51. doi:10.1016/i.psyneuen. 2009

114. Ivy AS, Rex CS, Chen Y, Dube C, Maras PM, Grigoriadis DE, et al. Hippocampal dysfunction and cognitive impairments provoked by chronic early-life stress involve excessive activation of CRH receptors. J Neurosci (2010) 30:13005-15. doi:10.1523/JNEUROSCI.1784-10.2010

115. Daskalakis NP, Diamantopoulou A, Claessens SE, Remmers E, Tjalve M, Oitzl MS, et al. Early experience of a novel-environment in isolation primes a fearful phenotype characterized by persistent amygdala activation. Psychoneuroendocrinology (2014) 39:39-57. doi:10.1016/j.psyneuen.2013.09.021

116. Butte JC, Kakihana R, Farnham ML, Noble EP. The relationship between brain and plasma corticosterone stress response in developing rats. Endocrinology (1973) 92:1775-9. doi:10.1210/endo-92-6-1775

117. Henning SJ. Plasma concentrations of total and free corticosterone during development in the rat. Am J Physiol (1978) 235:E451-6.

118. Guillet R, Saffran M, Michaelson SM. Pituitary-adrenal response in neonatal rats. Endocrinology (1980) 106:991-4. doi:10.1210/endo-106-3-991

119. Walker SJ, Vrana KE. Pituitary corticotroph function during the stress hyporesponsive period in neonatal rats. Neuroendocrinology (1993) 57:1003-10. doi:10.1159/000126464

120. Viau V, Sharma S, Meaney MJ. Changes in plasma adrenocorticotropin, corticosterone, corticosteroid-binding globulin, and hippocampal glucocorticoid receptor occupancy/translocation in rat pups in response to stress. J Neuroendocrinol (1996) 8:1-8. doi:10.1111/j.1365-2826.1996.tb00680.x

121. Vazquez DM. Stress and the developing limbic-hypothalamic-pituitaryadrenal axis. Psychoneuroendocrinology (1998) 23:663-700. doi:10.1016/ S0306-4530(98)00029-8 
122. Dallman MF. Moments in time - the neonatal rat hypothalamo-pituitaryadrenal axis. Endocrinology (2000) 141:1590-2. doi:10.1210/endo.141.5.7527

123. Petersen HH, Andreassen TK, Breiderhoff T, Brasen JH, Schulz H, Gross $\mathrm{V}$, et al. Hyporesponsiveness to glucocorticoids in mice genetically deficient for the corticosteroid binding globulin. Mol Cell Biol (2006) 26:7236-45. doi:10.1128/MCB.00400-06

124. Levine S. The pituitary-adrenal system and the developing brain. Prog Brain Res (1970) 32:79-85. doi:10.1016/S0079-6123(08)61521-6

125. Cote TE, Yasumura S. Effect of ACTH and histamine stress on serum corticosterone and adrenal cyclic AMP levels in immature rats. Endocrinology (1975) 96:1044-7. doi:10.1210/endo-96-4-1044

126. Martin CE, Cake MH, Hartmann PE, Cook IF. Relationship between foetal corticosteroids, maternal progesterone and parturition in the rat. Acta Endocrinol (Copenh) (1977) 84:167-76.

127. Walker CD, Perrin M, Vale W, Rivier C. Ontogeny of the stress response in the rat: role of the pituitary and the hypothalamus. Endocrinology (1986) 118:1445-51. doi:10.1210/endo-118-4-1445

128. Walker CD, Sapolsky RM, Meaney MJ, Vale WW, Rivier CL. Increased pituitary sensitivity to glucocorticoid feedback during the stress nonresponsive period in the neonatal rat. Endocrinology (1986) 119:1816-21. doi:10.1210/endo-1194- 1816

129. Levine S. The ontogeny of the hypothalamic-pituitary-adrenal axis. The influence of maternal factors. Ann N Y Acad Sci (1994) 746:275-88. doi:10.1111/j. 1749-6632.1994.tb39245.x

130. Grino M, Paulmyer-Lacroix O, Anglade G, Oliver C. Molecular aspects of the regulation of the hypothalamo-pituitary-adrenal axis during development in the rat. Ann N Y Acad Sci (1995) 771:339-51. doi:10.1111/j.1749-6632.1995. tb44693.x

131. Ramsay DS, Lewis M. Developmental change in infant cortisol and behavioral response to inoculation. Child Dev (1994) 65:1491-502. doi:10.2307/1131513

132. Gunnar MR, Brodersen L, Krueger K, Rigatuso J. Dampening of adrenocortical responses during infancy: normative changes and individual differences. Child Dev (1996) 67:877-89. doi:10.2307/1131867

133. Gunnar MR. Integrating neuroscience and psychological approaches in the study of early experiences. Ann N Y Acad Sci (2003) 1008:238-47. doi:10.1196/ annals.1301.024

134. Gunnar MR, Fisher PA. Bringing basic research on early experience and stress neurobiology to bear on preventive interventions for neglected and maltreated children. Dev Psychopathol (2006) 18:651-77. doi:10.1017/ S0954579406060330

135. Lupien SJ, McEwen BS, Gunnar MR, Heim C. Effects of stress throughout the lifespan on the brain, behaviour and cognition. Nat Rev Neurosci (2009) 10:434-45. doi:10.1038/nrn2639

136. Sapolsky RM, Meaney MJ. Maturation of the adrenocortical stress response: neuroendocrine control mechanisms and the stress hyporesponsive period. Brain Res (1986) 396:64-76. doi:10.1016/0165-0173(86)90010-X

137. Nachmias M, Gunnar M, Mangelsdorf S, Parritz RH, Buss K. Behavioral inhibition and stress reactivity: the moderating role of attachment security. Child $\operatorname{Dev}$ (1996) 67:508-22. doi:10.2307/1131829

138. Dettling AC, Parker SW, Lane S, Sebanc A, Gunnar MR. Quality of care and temperament determine changes in cortisol concentrations over the day for young children in childcare. Psychoneuroendocrinology (2000) 25:819-36. doi:10.1016/S0306-4530(00)00028-7

139. Gunnar MR, Donzella B. Social regulation of the cortisol levels in early human development. Psychoneuroendocrinology (2002) 27:199-220. doi:10. 1016/S0306-4530(01)00045-2

140. Levine S. Regulation of the hypothalamic-pituitary-adrenal axis in the neonatal rat: the role of maternal behavior. Neurotox Res (2002) 4:557-64. doi:10. 1080/10298420290030569

141. Schoenfeld NM, Leathem JH, Rabii J. Maturation of adrenal stress responsiveness in the rat. Neuroendocrinology (1980) 31:101-5. doi:10.1159/000123058

142. Walker CD, Scribner KA, Cascio CS, Dallman MF. The pituitary-adrenocortical system of neonatal rats is responsive to stress throughout development in a time-dependent and stressor-specific fashion. Endocrinology (1991) 128:1385-95. doi:10.1210/endo-128-3-1385

143. Yi SJ, Baram TZ. Corticotropin-releasing hormone mediates the response to cold stress in the neonatal rat without compensatory enhancement of the peptide's gene expression. Endocrinology (1994) 135:2364-8. doi:10.1210/endo. 135.6 .7988418
144. Hatalski CG, Guirguis C, Baram TZ. Corticotropin releasing factor mRNA expression in the hypothalamic paraventricular nucleus and the central nucleus of the amygdala is modulated by repeated acute stress in the immature rat. J Neuroendocrinol (1998) 10:663-9. doi:10.1046/j.1365-2826.1998. 00246.x

145. Dent GW, Okimoto DK, Smith MA, Levine S. Stress-induced alterations in corticotropin-releasing hormone and vasopressin gene expression in the paraventricular nucleus during ontogeny. Neuroendocrinology (2000) 71:333-42. doi:10.1159/000054554

146. Meaney MJ, Sapolsky RM, McEwen BS. The development of the glucocorticoid receptor system in the rat limbic brain. II. An autoradiographic study. Brain Res (1985) 350:165-8. doi:10.1016/0165-3806(85)90260-3

147. Alexis MN, Kitraki E, Spanou K, Stylianopoulou F, Sekeris CE. Ontogeny of the glucocorticoid receptor in the rat brain. Adv Exp Med Biol (1990) 265:269-76. doi:10.1007/978-1-4757-5876-4_25

148. Stanton ME, Levine S. Inhibition of infant glucocorticoid stress response: specific role of maternal cues. Dev Psychobiol (1990) 23:411-26. doi:10.1002/dev. 420230504

149. Widmaier EP. Glucose homeostasis and hypothalamic-pituitaryadrenocortical axis during development in rats. Am J Physiol (1990) 259:E601-13.

150. Arai M, Widmaier EP. Activation of the pituitary-adrenocortical axis in dayold rats by insulin-induced hypoglycemia. Endocrinology (1991) 129:1505-12. doi:10.1210/endo-129-3-1505

151. Rosenfeld P, Van Eekelen JA, Levine S, De Kloet ER. Ontogeny of corticosteroid receptors in the brain. Cell Mol Neurobiol (1993) 13:295-319. doi:10.1007/BF00711575

152. Suchecki D, Rosenfeld P, Levine S. Maternal regulation of the hypothalamicpituitary-adrenal axis in the infant rat: the roles of feeding and stroking. Brain Res Dev Brain Res (1993) 75:185-92. doi:10.1016/0165-3806(93)90022-3

153. Eghbal-Ahmadi M, Avishai-Eliner S, Hatalski CG, Baram TZ. Differential regulation of the expression of corticotropin-releasing factor receptor type 2 (CRF2) in hypothalamus and amygdala of the immature rat by sensory input and food intake. J Neurosci (1999) 19:3982-91.

154. Hofer MA. Psychobiological roots of early attachment. Curr Dir Psychol Sci (2006) 15:84-8. doi:10.1111/j.0963-7214.2006.00412.x

155. Baram TZ, Yi S, Avishai-Eliner S, Schultz L. Development neurobiology of the stress response: multilevel regulation of corticotropin-releasing hormone function. Ann N Y Acad Sci (1997) 814:252-65. doi:10.1111/j.1749-6632.1997. tb46161.x

156. Avishai-Eliner S, Gilles EE, Eghbal-Ahmadi M, Bar-El Y, Baram TZ. Altered regulation of gene and protein expression of hypothalamic-pituitary-adrenal axis components in an immature rat model of chronic stress. JNeuroendocrinol (2001) 13:799-807. doi:10.1046/j.1365-2826.2001.00698.x

157. Avishai-Eliner S, Eghbal-Ahmadi M, Tabachnik E, Brunson KL, Baram TZ. Down-regulation of hypothalamic corticotropin-releasing hormone messenger ribonucleic acid (mRNA) precedes early-life experience-induced changes in hippocampal glucocorticoid receptor mRNA. Endocrinology (2001) 142:89-97. doi:10.1210/en.142.1.89

158. Sanchez MM. The impact of early adverse care on HPA axis development: nonhuman primate models. Horm Behav (2006) 50:623-31. doi:10.1016/j.yhbeh. 2006.06.012

159. Kaffman A, Meaney MJ. Neurodevelopmental sequelae of postnatal maternal care in rodents: clinical and research implications of molecular insights. J Child Psychol Psychiatry (2007) 48:224-44. doi:10.1111/j.1469-7610.2007.01730.x

160. Howell BR, Sanchez MM. Understanding behavioral effects of early life stress using the reactive scope and allostatic load models. Dev Psychopathol (2011) 23:1001-16. doi:10.1017/S0954579411000460

161. Bolhuis JJ, Honey RC. Imprinting, learning and development: from behaviour to brain and back. Trends Neurosci (1998) 21:306-11. doi:10.1016/S01662236(98)01258-2

162. Ziabreva I, Poeggel G, Schnabel R, Braun K. Separation-induced receptor changes in the hippocampus and amygdala of Octodon degus: influence of maternal vocalizations. J Neurosci (2003) 23:5329-36.

163. Insel TR, Young LJ. The neurobiology of attachment. Nat Rev Neurosci (2001) 2:129-36. doi:10.1038/35053579

164. Herman JP, Cullinan WE. Neurocircuitry of stress: central control of the hypothalamo-pituitary-adrenocortical axis. Trends Neurosci (1997) 20:78-84. doi:10.1016/S0166-2236(96)10069-2 
165. Sullivan RM, Landers M, Yeaman B, Wilson DA. Good memories of bad events in infancy. Nature (2000) 407:38-9. doi:10.1038/35024156

166. Moriceau S, Sullivan RM. Maternal presence serves as a switch between learning fear and attraction in infancy. Nat Neurosci (2006) 9:1004-6. doi:10.1038/ nn 1733

167. Shionoya K, Moriceau S, Bradstock P, Sullivan RM. Maternal attenuation of hypothalamic paraventricular nucleus norepinephrine switches avoidance learning to preference learning in preweanling rat pups. Horm Behav (2007) 52:391-400. doi:10.1016/j.yhbeh.2007.06.004

168. Miller SS, Spear NE. Olfactory learning in the rat neonate soon after birth. Dev Psychobiol (2008) 50:554-65. doi:10.1002/dev.20318

169. Sullivan RM, Holman PJ. Transitions in sensitive period attachment learning in infancy: the role of corticosterone. Neurosci Biobehav Rev (2010) 34:835-44. doi:10.1016/j.neubiorev.2009.11.010

170. Leon M. Dietary control of maternal pheromone in the lactating rat. Physiol Behav (1975) 14:311-9. doi:10.1016/0031-9384(75)90039-6

171. Pedersen PE, Williams CL, Blass EM. Activation and odor conditioning of suckling behavior in 3-day-old albino rats. J Exp Psychol Anim Behav Process (1982) 8:329-41. doi:10.1037/0097-7403.8.4.329

172. Leon M. Neuroethology of olfactory preference development. J Neurobiol (1992) 23:1557-73. doi:10.1002/neu.480231012

173. Kojima S, Alberts JR. Maternal care can rapidly induce an odor-guided huddling preference in rat pups. Dev Psychobiol (2009) 51:95-105. doi:10.1002/ dev.20349

174. Moriceau S, Roth TL, Sullivan RM. Rodent model of infant attachment learning and stress. Dev Psychobiol (2010) 52:651-60. doi:10.1002/dev.20482

175. Landers MS, Sullivan RM. The development and neurobiology of infant attachment and fear. Dev Neurosci (2012) 34:101-14. doi:10.1159/000336732

176. Singh PJ, Tobach E. Olfactory bulbectomy and nursing behavior in rat pups (Wistar DAB). Dev Psychobiol (1975) 8:151-64. doi:10.1002/dev.420080207

177. Galef BG Jr, Kaner HC. Establishment and maintenance of preference for natural and artificial olfactory stimuli in juvenile rats. J Comp Physiol Psychol (1980) 94:588-95. doi:10.1037/h0077693

178. Galef BG Jr. Acquisition and waning of exposure-induced attraction to a nonnatural odor in rat pups. Dev Psychobiol (1982) 15:479-90. doi:10.1002/dev. 420150510

179. Alberts JR, May B. Nonnutritive, thermotactile induction of filial huddling in rat pups. Dev Psychobiol (1984) 17:161-81. doi:10.1002/dev.420170207

180. Caza PA, Spear NE. Short-term exposure to an odor increases its subsequent preference in preweanling rats: a descriptive profile of the phenomenon. Dev Psychobiol (1984) 17:407-22. doi:10.1002/dev.420170407

181. Duveau A, Godinot F. Influence of the odorization of the rearing environment on the development of odor-guided behavior in rat pups. Physiol Behav (1988) 42:265-70. doi:10.1016/0031-9384(88)90080-7

182. Sullivan RM, Wilson DA, Wong R, Correa A, Leon M. Modified behavioral and olfactory bulb responses to maternal odors in preweanling rats. Brain Res Dev Brain Res (1990) 53:243-7. doi:10.1016/0165-3806(90)90013-O

183. Johanson IB, Hall WG. Appetitive learning in 1-day-old rat pups. Science (1979) 205:419-21. doi:10.1126/science.451612

184. Johanson IB, Teicher MH. Classical conditioning of an odor preference in 3day-old rats. Behav Neural Biol (1980) 29:132-6. doi:10.1016/S0163-1047(80) 92596-0

185. Brake SC. Suckling infant rats learn a preference for a novel olfactory stimulus paired with milk delivery. Science (1981) 211:506-8. doi:10.1126/science. 7192882

186. Sullivan RM, Leon M. Early olfactory learning induces an enhanced olfactory bulb response in young rats. Brain Res (1986) 392:278-82. doi:10.1016/01653806(86)90256-7

187. Sullivan RM, Wilson DA. Neural correlates of conditioned odor avoidance in infant rats. Behav Neurosci (1991) 105:307-12. doi:10.1037/0735-7044.105.2. 307

188. Moriceau S, Shionoya K, Jakubs K, Sullivan RM. Early-life stress disrupts attachment learning: the role of amygdala corticosterone, locus coeruleus corticotropin releasing hormone, and olfactory bulb norepinephrine. J Neurosci (2009) 29:15745-55. doi:10.1523/JNEUROSCI.4106-09.2009

189. Levine S. Plasma-free corticosteroid response to electric shock in rats stimulated in infancy. Science (1962) 135:795-6. doi:10.1126/science.135.3506.795-a
190. Haroutunian V, Campbell BA. Emergence of interoceptive and exteroceptive control of behavior in rats. Science (1979) 205:927-9. doi:10.1126/science. 472715

191. Camp LL, Rudy JW. Changes in the categorization of appetitive and aversive events during postnatal development of the rat. Dev Psychobiol (1988) 21:25-42. doi:10.1002/dev.420210103

192. Otto T, Cousens G, Rajewski K. Odor-guided fear conditioning in rats: 1. Acquisition, retention, and latent inhibition. Behav Neurosci (1997) 111:1257-64 doi:10.1037/0735-7044.111.6.1257

193. Paschall GY, Davis M. Olfactory-mediated fear-potentiated startle. Behav Neurosci (2002) 116:4-12. doi:10.1037/0735-7044.116.1.4

194. Collier AC, Bolles RC. The ontogenesis of defensive reactions to shock in preweanling rats. Dev Psychobiol (1980) 13:141-50. doi:10.1002/dev. 420130206

195. Emerich DF, Scalzo FM, Enters EK, Spear NE, Spear LP. Effects of 6hydroxydopamine-induced catecholamine depletion on shock-precipitated wall climbing of infant rat pups. Dev Psychobiol (1985) 18:215-27. doi:10. 1002/dev.420180303

196. Barr GA. Ontogeny of nociception and antinociception. NIDA Res Monogr (1995) 158:172-201.

197. Fitzgerald M. The development of nociceptive circuits. Nat Rev Neurosci (2005) 6:507-20. doi:10.1038/nrn1701

198. Fanselow MS, LeDoux JE. Why we think plasticity underlying Pavlovian fear conditioning occurs in the basolateral amygdala. Neuron (1999) 23:229-32. doi:10.1016/S0896-6273(00)80775-8

199. Fendt M, Fanselow MS. The neuroanatomical and neurochemical basis of conditioned fear. Neurosci Biobehav Rev (1999) 23:743-60. doi:10.1016/S01497634(99)00016-0

200. Maren S. The amygdala, synaptic plasticity, and fear memory. Ann N Y Acad Sci (2003) 985:106-13. doi:10.1111/j.1749-6632.2003.tb07075.x

201. Moriceau S, Wilson DA, Levine S, Sullivan RM. Dual circuitry for odor-shock conditioning during infancy: corticosterone switches between fear and attraction via amygdala. J Neurosci (2006) 26:6737-48. doi:10.1523/JNEUROSCI. 0499-06.2006

202. Johansen JP, Cain CK, Ostroff LE, Ledoux JE. Molecular mechanisms of fear learning and memory. Cell (2011) 147:509-24. doi:10.1016/j.cell.2011.10.009

203. Sullivan RM. Unique characteristics of neonatal classical conditioning: the role of the amygdala and locus coeruleus. Integr Physiol Behav Sci (2001) 36:293-307. doi:10.1007/BF02688797

204. Coopersmith R, Lee S, Leon M. Olfactory bulb responses after odor aversion learning by young rats. Brain Res (1986) 389:271-7. doi:10.1016/01653806(86)90195-1

205. Wilson DA, Sullivan RM, Leon M. Single-unit analysis of postnatal olfactory learning: modified olfactory bulb output response patterns to learned attractive odors. J Neurosci (1987) 7:3154-62.

206. McLean JH, Harley CW, Darby-King A, Yuan Q. pCREB in the neonate rat olfactory bulb is selectively and transiently increased by odor preferenceconditioned training. Learn Mem (1999) 6:608-18. doi:10.1101/lm.6.6.608

207. Yuan Q, Harley CW, Darby-King A, Neve RL, McLean JH. Early odor preference learning in the rat: bidirectional effects of cAMP response element-binding protein (CREB) and mutant CREB support a causal role for phosphorylated CREB. J Neurosci (2003) 23:4760-5.

208. Zhang JJ, Okutani F, Inoue S, Kaba H. Activation of the cyclic AMP response element-binding protein signaling pathway in the olfactory bulb is required for the acquisition of olfactory aversive learning in young rats. Neuroscience (2003) 117:707-13. doi:10.1016/S0306-4522(02)00962-4

209. Yuan Q, Mutoh H, Debarbieux F, Knopfel T. Calcium signaling in mitral cell dendrites of olfactory bulbs of neonatal rats and mice during olfactory nerve stimulation and beta-adrenoceptor activation. Learn Mem (2004) 11:406-11. doi:10.1101/lm.75204

210. Yuan Q. Theta bursts in the olfactory nerve paired with beta-adrenoceptor activation induce calcium elevation in mitral cells: a mechanism for odor preference learning in the neonate rat. Learn Mem (2009) 16:676-81. doi:10.1101/ $\operatorname{lm} .1569309$

211. Woo CC, Coopersmith R, Leon M. Localized changes in olfactory bulb morphology associated with early olfactory learning. J Comp Neurol (1987) 263:113-25, doi:10.1002/cne.902630110 
212. Johnson BA, Woo CC, Duong H, Nguyen V, Leon M. A learned odor evokes an enhanced Fos-like glomerular response in the olfactory bulb of young rats. Brain Res (1995) 699:192-200. doi:10.1016/0006-8993(95)00896-X

213. Yuan Q, Harley CW, McLean JH, Knopfel T. Optical imaging of odor preference memory in the rat olfactory bulb. J Neurophysiol (2002) 87:3156-9.

214. Shakhawat AM, Harley CW, Yuan Q. Olfactory bulb alpha 2-adrenoceptor activation promotes rat pup odor-preference learning via a cAMP-independent mechanism. Learn Mem (2012) 19:499-502. doi:10.1101/lm.027359.112

215. Wilson DA, Leon M. Spatial patterns of olfactory bulb single-unit responses to learned olfactory cues in young rats. J Neurophysiol (1988) 59:1770-82.

216. Sullivan RM, Wilson DA. Role of the amygdala complex in early olfactory associative learning. Behav Neurosci (1993) 107:254-63. doi:10.1037/0735-7044. 107.2.254

217. Wiedenmayer CP, Barr GA. Developmental changes in c-fos expression to an age-specific social stressor in infant rats. Behav Brain Res (2001) 126:147-57. doi:10.1016/S0166-4328(01)00260-1

218. Thompson JV, Sullivan RM, Wilson DA. Developmental emergence of fear learning corresponds with changes in amygdala synaptic plasticity. Brain Res (2008) 1200:58-65. doi:10.1016/j.brainres.2008.01.057

219. Sullivan RM, Hofer MA, Brake SC. Olfactory-guided orientation in neonatal rats is enhanced by a conditioned change in behavioral state. Dev Psychobiol (1986) 19:615-23. doi:10.1002/dev.420190612

220. Shipley MT, Halloran FJ, De La Torre J. Surprisingly rich projection from locus coeruleus to the olfactory bulb in the rat. Brain Res (1985) 329:294-9. doi:10.1016/0006-8993(85)90537-2

221. McLean JH, Shipley MT. Postnatal development of the noradrenergic projection from locus coeruleus to the olfactory bulb in the rat. J Comp Neurol (1991) 304:467-77. doi:10.1002/cne.903040310

222. Nakamura S, Kimura F, Sakaguchi T. Postnatal development of electrical activity in the locus coeruleus. J Neurophysiol (1987) 58:510-24.

223. Nakamura S, Sakaguchi T. Development and plasticity of the locus coeruleus: a review of recent physiological and pharmacological experimentation. Prog Neurobiol (1990) 34:505-26. doi:10.1016/0301-0082(90)90018-C

224. Marshall KC, Christie MJ, Finlayson PG, Williams JT. Developmental aspects of the locus coeruleus-noradrenaline system. Prog Brain Res (1991) 88:173-85. doi:10.1016/S0079-6123(08)63807-8

225. Rangel S, Leon M. Early odor preference training increases olfactory bulb norepinephrine. Brain Res Dev Brain Res (1995) 85:187-91. doi:10.1016/01653806(94)00211-H

226. Winzer-Serhan UH, Leslie FM. Expression of alpha 2A adrenoceptors during rat neocortical development. J Neurobiol (1999) 38:259-69. doi:10.1002/(SICI) 1097-4695(19990205)38:2<259::AID-NEU8>3.0.CO;2-U

227. Moriceau S, Sullivan RM. Unique neural circuitry for neonatal olfactory learning. J Neurosci (2004) 24:1182-9. doi:10.1523/JNEUROSCI.4578-03.2004

228. Sullivan RM, Zyzak DR, Skierkowski P, Wilson DA. The role of olfactory bulb norepinephrine in early olfactory learning. Brain Res Dev Brain Res (1992) 70:279-82. doi:10.1016/0165-3806(92)90207-D

229. Sullivan RM, Wilson DA. The locus coeruleus, norepinephrine, and memory in newborns. Brain Res Bull (1994) 35:467-72. doi:10.1016/0361-9230(94) 90160-0

230. Sullivan RM, Wilson DA, Lemon C, Gerhardt GA. Bilateral 6-OHDA lesions of the locus coeruleus impair associative olfactory learning in newborn rats. Brain Res (1994) 643:306-9. doi:10.1016/0006-8993(94)90038-8

231. Langdon PE, Harley CW, McLean JH. Increased beta adrenoceptor activation overcomes conditioned olfactory learning deficits induced by serotonin depletion. Brain Res Dev Brain Res (1997) 102:291-3. doi:10.1016/S0165-3806(97) 00090-4

232. Sullivan RM, Stackenwalt G, Nasr F, Lemon C, Wilson DA. Association of an odor with activation of olfactory bulb noradrenergic beta-receptors or locus coeruleus stimulation is sufficient to produce learned approach responses to that odor in neonatal rats. Behav Neurosci (2000) 114:957-62. doi:10.1037/0735-7044.114.5.957

233. Fanselow MS, Gale GD. The amygdala, fear, and memory. Ann N Y Acad Sci (2003) 985:125-34. doi:10.1111/j.1749-6632.2003.tb07077.x

234. Blozovski D, Cudennec A. Passive avoidance learning in the young rat. Dev Psychobiol (1980) 13:513-8. doi:10.1002/dev.420130510

235. Myslivecek J. Inhibitory learning and memory in newborn rats. Prog Neurobiol (1997) 53:399-430. doi:10.1016/S0301-0082(97)00036-1
236. Stanton ME. Multiple memory systems, development and conditioning. Behav Brain Res (2000) 110:25-37. doi:10.1016/S0166-4328(99)00182-5

237. Sullivan RM. Developmental changes in olfactory behavior and limbic circuitry. Chem Senses (2005) 30(Suppl 1):i152-3. doi:10.1093/chemse/bjh159

238. Moriceau S, Sullivan RM. Neurobiology of infant attachment. Dev Psychobiol (2005) 47:230-42. doi:10.1002/dev.20093

239. Takahashi LK, Rubin WW. Corticosteroid induction of threat-induced behavioral inhibition in preweanling rats. Behav Neurosci (1993) 107:860-6. doi:10. 1037/0735-7044.107.5.860

240. Takahashi LK. Organizing action of corticosterone on the development of behavioral inhibition in the preweanling rat. Brain Res Dev Brain Res (1994) 81:121-7. doi:10.1016/0165-3806(94)90074-4

241. Moriceau S, Sullivan RM. Corticosterone influences on mammalian neonatal sensitive-period learning. Behav Neurosci (2004) 118:274-81. doi:10.1037/ 0735-7044.118.2.274

242. Moriceau S, Roth TL, Okotoghaide T, Sullivan RM. Corticosterone controls the developmental emergence of fear and amygdala function to predator odors in infant rat pups. Int J Dev Neurosci (2004) 22:415-22. doi:10.1016/j.ijdevneu. 2004.05.011

243. Barr GA, Moriceau S, Shionoya K, Muzny K, Gao P, Wang S, et al. Transitions in infant learning are modulated by dopamine in the amygdala. Nat Neurosci (2009) 12:1367-9. doi:10.1038/nn.2403

244. Collier AC, Mast J, Meyer DR, Jacobs CE. Approach-avoidance conflict in preweanling rats: a developmental study. Anim Learn Behav (1979) 7:514-20. doi:10.3758/BF03209712

245. Sullivan RM, Wilson DA, Leon M. Norepinephrine and learning-induced plasticity in infant rat olfactory system. J Neurosci (1989) 9:3998-4006.

246. Sullivan RM, Wilson DA. The role of norepinephrine in the expression of learned olfactory neurobehavioral responses in infant rats. Psychobiology (Austin, Tex) (1991) 19:308-12.

247. Sullivan RM, Moriceau S, Raineki C, Roth T. Ontogeny of infant fear learning and amygdala. In: Gazzaniga MS, editor. Cognitive Neuroscience. Cambridge: MIT Press (2009). p. 889-904.

248. Vogt JL, Coe CL, Levine S. Behavioral and adrenocorticoid responsiveness of squirrel monkeys to a live snake: is flight necessarily stressful? Behav Neural Biol (1981) 32:391-405. doi:10.1016/S0163-1047(81)90826-8

249. Hennessy MB. Presence of companion moderates arousal of monkeys with restricted social experience. Physiol Behav (1984) 33:693-8. doi:10.1016/00319384(84)90033-7

250. Kirschbaum C, Klauer T, Filipp SH, Hellhammer DH. Sex-specific effects of social support on cortisol and subjective responses to acute psychological stress. Psychosom Med (1995) 57:23-31.

251. Heinrichs M, Baumgartner T, Kirschbaum C, Ehlert U. Social support and oxytocin interact to suppress cortisol and subjective responses to psychosocial stress. Biol Psychiatry (2003) 54:1389-98. doi:10.1016/S0006-3223(03) 00465-7

252. Taylor SE, Burklund LJ, Eisenberger NI, Lehman BJ, Hilmert CJ, Lieberman MD. Neural bases of moderation of cortisol stress responses by psychosocial resources. J Pers Soc Psychol (2008) 95:197-211. doi:10.1037/0022-3514. 95.1.197

253. Hostinar CE, Sullivan RM, Gunnar MR. Psychobiological mechanisms underlying the social buffering of the hypothalamic-pituitary-adrenocortical axis: a review of animal models and human studies across development. Psychol Bull (2013) 140(1):256-82. doi:10.1037/a0032671

254. Stanton ME, Wallstrom J, Levine S. Maternal contact inhibits pituitaryadrenal stress responses in preweanling rats. Dev Psychobiol (1987) 20:131-45. doi:10.1002/dev.420200204

255. Wiedenmayer CP, Magarinos AM, McEwen BS, Barr G. Mother lowers glucocorticoid levels of preweaning rats after acute threat. Ann N Y Acad Sci (2003) 1008:304-7. doi:10.1196/annals. 1301.038

256. DeVries AC, Glasper ER, Detillion CE. Social modulation of stress responses. Physiol Behav (2003) 79:399-407. doi:10.1016/S0031-9384(03)00152-5

257. Kikusui T, Winslow JT, Mori Y. Social buffering: relief from stress and anxiety. Philos Trans R Soc Lond B Biol Sci (2006) 361:2215-28. doi:10.1098/rstb.2006. 1941

258. Hennessy MB, Kaiser S, Sachser N. Social buffering of the stress response: diversity, mechanisms, and functions. Front Neuroendocrinol (2009) 30:470-82. doi:10.1016/j.yfrne.2009.06.001 
259. Takahashi Y, Kiyokawa Y, Kodama Y, Arata S, Takeuchi Y, Mori Y. Olfactory signals mediate social buffering of conditioned fear responses in male rats. Behav Brain Res (2013) 240:46-51. doi:10.1016/j.bbr.2012.11.017

260. Upton KJ, Sullivan RM. Defining age limits of the sensitive period for attachment learning in rat pups. Dev Psychobiol (2010) 52:453-64. doi:10.1002/dev. 20448

261. Gunnar MR, Brodersen L, Nachmias M, Buss K, Rigatuso J. Stress reactivity and attachment security. Dev Psychobiol (1996) 29:191-204. doi:10.1002/ (SICI) 1098-2302(199604)29:3<191::AID-DEV1>3.3.CO;2-T

262. Eisenberg L. The biosocial context of parenting in human families. In: Krasnegor NAB Sr, editor. Mammalian Parenting Biochemical, Neurobiological, and Behavioral Determinants. New York, NY: Oxford University Press (1990). p. 9-24.

263. Field T. Child abuse in monkeys and humans: a comparative perspective. In: Reite M, Caine NG, editors. Child Abuse: The Nonhuman Primate Data. New York, NY: Alan R Liss, Inc. (1983). p. 151-74.

264. Schapiro S, Mitchel G. Infant-directed abuse in a seminatural environment: precipitating factors. In: Reite M, Caine NG, editors. Child Abuse: The Nonhuman Primate Data. New York, NY: Alan R Liss, Inc. (1983). p. 29-48.

265. Rice CJ, Sandman CA, Lenjavi MR, Baram TZ. A novel mouse model for acute and long-lasting consequences of early life stress. Endocrinology (2008) 149:4892-900. doi:10.1210/en.2008-0633

266. Pedersen CA, Caldwell JD, McGuire M, Evans DL. Corticotropin-releasing hormone inhibits maternal behavior and induces pup-killing. Life Sci (1991) 48:1537-46. doi:10.1016/0024-3205(91)90278-J

267. Yeh KY. Corticosterone concentrations in the serum and milk of lactating rats: parallel changes after induced stress. Endocrinology (1984) 115:1364-70. doi:10.1210/endo-115-4-1364

268. McEwen BS, Seeman T. Protective and damaging effects of mediators of stress. Elaborating and testing the concepts of allostasis and allostatic load. Ann N Y Acad Sci (1999) 896:30-47. doi:10.1111/j.1749-6632.1999.tb08103.x

269. McEwen BS. The neurobiology of stress: from serendipity to clinical relevance. Brain Res (2000) 886:172-89. doi:10.1016/S0006-8993(00)02950-4

270. Weinstock M. The potential influence of maternal stress hormones on development and mental health of the offspring. Brain Behav Immun (2005) 19:296-308. doi:10.1016/j.bbi.2004.09.006

271. Cone RD, Low MJ, Elmquist JK, Cameron JL. Neuroendocrinology. 12th ed. In: Larsen PR, Melmed S, Polonsky KS, editors. Williams Textbook of Endocrinology. Philadelphia, PA: Saunders (2003). p. 81-176.

272. Herman JP, Figueiredo H, Mueller NK, Ulrich-Lai Y, Ostrander MM, Choi DC, et al. Central mechanisms of stress integration: hierarchical circuitry controlling hypothalamo-pituitary-adrenocortical responsiveness. Front Neuroendocrinol (2003) 24:151-80. doi:10.1016/j.yfrne.2003.07.001

273. Munck A, Guyre PM, Holbrook NJ. Physiological functions of glucocorticoids in stress and their relation to pharmacological actions. Endocr Rev (1984) 5:25-44. doi:10.1210/edrv-5-1-25

274. Dallman MF, Akana SF, Strack AM, Hanson ES, Sebastian RJ. The neural network that regulates energy balance is responsive to glucocorticoids and insulin and also regulates HPA axis responsivity at a site proximal to CRF neurons. Ann N Y Acad Sci (1995) 771:730-42. doi:10.1111/j.1749-6632.1995. tb44724.x

275. Sapolsky RM, Romero LM, Munck AU. How do glucocorticoids influence stress responses? Integrating permissive, suppressive, stimulatory, and preparative actions. Endocr Rev (2000) 21:55-89. doi:10.1210/er.21.1.55

276. Seckl JR. Glucocorticoids, ageing and nerve cell damage. J Neuroendocrinol (2000) 12:709-10.

277. Thierry AM, Tassin JP, Blanc G, Glowinski J. Selective activation of mesocortical DA system by stress. Nature (1976) 263:242-4. doi:10.1038/263242a0

278. Herman JP, Guillonneau D, Dantzer R, Scatton B, Semerdjian-Rouquier L, Le Moal M. Differential effects of inescapable footshocks and of stimuli previously paired with inescapable footshocks on dopamine turnover in cortical and limbic areas of the rat. Life Sci (1982) 30:2207-14. doi:10.1016/0024-3205(82) 90295-8

279. Abercrombie ED, Jacobs BL. Single-unit response of noradrenergic neurons in the locus coeruleus of freely moving cats. I. Acutely presented stressful and nonstressful stimuli. J Neurosci (1987) 7:2837-43.

280. Adell A, Garcia-Marquez C, Armario A, Gelpi E. Chronic stress increases serotonin and noradrenaline in rat brain and sensitizes their responses to a further acute stress. J Neurochem (1988) 50:1678-81. doi:10.1111/j.1471-4159.1988. tb02462.x

281. Abercrombie ED, Keefe KA, Difrischia DS, Zigmond MJ. Differential effect of stress on in vivo dopamine release in striatum, nucleus accumbens, and medial frontal cortex. J Neurochem (1989) 52:1655-8. doi:10.1111/j.1471-4159.1989. tb09224.x

282. Deutch AY, Roth RH. The determinants of stress-induced activation of the prefrontal cortical dopamine system. Prog Brain Res (1990) 85:367-402. doi:10.1016/S0079-6123(08)62691-6

283. Pei Q, Zetterstrom T, Fillenz M. Tail pinch-induced changes in the turnover and release of dopamine and 5-hydroxytryptamine in different brain regions of the rat. Neuroscience (1990) 35:133-8. doi:10.1016/0306-4522(90)90127-P

284. Nisenbaum LK, Zigmond MJ, Sved AF, Abercrombie ED. Prior exposure to chronic stress results in enhanced synthesis and release of hippocampal norepinephrine in response to a novel stressor. J Neurosci (1991) 11:1478-84.

285. Inoue $\mathrm{T}$, Tsuchiya $\mathrm{K}$, Koyama T. Regional changes in dopamine and serotonin activation with various intensity of physical and psychological stress in the rat brain. Pharmacol Biochem Behav (1994) 49:911-20. doi:10.1016/00913057(94)90243-7

286. Finlay JM, Zigmond MJ, Abercrombie ED. Increased dopamine and norepinephrine release in medial prefrontal cortex induced by acute and chronic stress: effects of diazepam. Neuroscience (1995) 64:619-28. doi:10.1016/03064522(94)00331-X

287. Makino S, Schulkin J, Smith MA, Pacak K, Palkovits M, Gold PW. Regulation of corticotropin-releasing hormone receptor messenger ribonucleic acid in the rat brain and pituitary by glucocorticoids and stress. Endocrinology (1995) 136:4517-25. doi:10.1210/en.136.10.4517

288. Inglis FM, Moghaddam B. Dopaminergic innervation of the amygdala is highly responsive to stress. J Neurochem (1999) 72:1088-94. doi:10.1046/j.1471-4159. 1999.0721088.x

289. Kaehler ST, Singewald N, Sinner C, Thurnher C, Philippu A. Conditioned fear and inescapable shock modify the release of serotonin in the locus coeruleus. Brain Res (2000) 859:249-54. doi:10.1016/S0006-8993(00)01967-3

290. McEwen BS. Protective and damaging effects of stress mediators. N Engl J Med (1998) 338:171-9. doi:10.1056/NEJM199801153380307

291. Herbert J, Goodyer IM, Grossman AB, Hastings MH, De Kloet ER, Lightman SL, et al. Do corticosteroids damage the brain? J Neuroendocrinol (2006) 18:393-411. doi:10.1111/j.1365-2826.2006.01429.x

292. Chrousos GP. Stress and disorders of the stress system. Nat Rev Endocrinol (2009) 5:374-81. doi:10.1038/nrendo.2009.106

293. Nelson CA, Carver LJ. The effects of stress and trauma on brain and memory: a view from developmental cognitive neuroscience. Dev Psychopathol (1998) 10:793-809. doi:10.1017/S0954579498001874

294. Toth SL, Cicchetti D. Remembering, forgetting, and the effects of trauma on memory: a developmental psychopathology perspective. Dev Psychopathol (1998) 10:589-605. doi:10.1017/S0954579498001771

295. Matthews SG. Early programming of the hypothalamo-pituitary-adrenal axis. Trends Endocrinol Metab (2002) 13:373-80. doi:10.1016/S1043-2760(02) 00690-2

296. Tottenham N, Sheridan MA. A review of adversity, the amygdala and the hippocampus: a consideration of developmental timing. Front Hum Neurosci (2009) 3:68. doi:10.3389/neuro.09.068.2009

297. Pechtel P, Pizzagalli DA. Effects of early life stress on cognitive and affective function: an integrated review of human literature. Psychopharmacology (Berl) (2011) 214:55-70. doi:10.1007/s00213-010-2009-2

298. Suomi SJ. Early stress and adult emotional reactivity in rhesus monkeys. Ciba Found Symp (1991) 156:171-83.

299. Gunnar M, Vazquez D. Stress neurobiology and developmental psychopathology. In: Cicchetti DCD, editor. Developmental Psychopathology: Developmental Neuroscience. New York, NY: Wiley (2006). p. 533-77.

300. Andrews MH, Matthews SG. Programming of the hypothalamo-pituitaryadrenal axis: serotonergic involvement. Stress (2004) 7:15-27. doi:10.1080/ 10253890310001650277

301. Rodrigues AJ, Leao P, Carvalho M, Almeida OF, Sousa N. Potential programming of dopaminergic circuits by early life stress. Psychopharmacology (Berl) (2011) 214:107-20. doi:10.1007/s00213-010-2085-3

302. De Kloet ER, Rots NY, Cools AR. Brain-corticosteroid hormone dialogue: slow and persistent. Cell Mol Neurobiol (1996) 16:345-56. doi:10.1007/BF02088100 
303. Diorio D, Viau V, Meaney MJ. The role of the medial prefrontal cortex (cingulate gyrus) in the regulation of hypothalamic-pituitary-adrenal responses to stress. J Neurosci (1993) 13:3839-47.

304. Sullivan RM, Gratton A. Prefrontal cortical regulation of hypothalamicpituitary-adrenal function in the rat and implications for psychopathology: side matters. Psychoneuroendocrinology (2002) 27:99-114. doi:10.1016/S03064530(01)00038-5

305. Herman JP, Ostrander MM, Mueller NK, Figueiredo H. Limbic system mechanisms of stress regulation: hypothalamo-pituitary-adrenocortical axis. Prog Neuropsychopharmacol Biol Psychiatry (2005) 29:1201-13. doi:10.1016/j. pnpbp.2005.08.006

306. Jankord R, Herman JP. Limbic regulation of hypothalamo-pituitaryadrenocortical function during acute and chronic stress. Ann N Y Acad Sci (2008) 1148:64-73. doi:10.1196/annals.1410.012

307. Ulrich-Lai YM, Herman JP. Neural regulation of endocrine and autonomic stress responses. Nat Rev Neurosci (2009) 10:397-409. doi:10.1038/nrn2647

308. Cunningham MG, Bhattacharyya S, Benes FM. Amygdalo-cortical sprouting continues into early adulthood: implications for the development of normal and abnormal function during adolescence. J Comp Neurol (2002) 453:116-30.

309. Andersen SL, Teicher MH. Stress, sensitive periods and maturational events in adolescent depression. Trends Neurosci (2008) 31:183-91. doi:10.1016/j.tins. 2008.01.004

310. Teicher MH, Andersen SL, Polcari A, Anderson CM, Navalta CP. Developmental neurobiology of childhood stress and trauma. Psychiatr Clin North Am (2002) 25:397-426, vii-viii. doi:10.1016/S0193-953X(01)00003-X

311. Meaney MJ. Plasticity and health: social influences on gene expression and neural development. In: Kessel F, Rosenfeld PL, Anderson NB, editors. Expanding the Boundaries of Health and Social Science: Case Studies in Interdisciplinary Innovation. New York, NY: Oxford University Press (2008). 147 p.

312. Loman MM, Gunnar MR. Early experience and the development of stress reactivity and regulation in children. Neurosci Biobehav Rev (2010) 34:867-76. doi:10.1016/j.neubiorev.2009.05.007

313. Nemeroff CB, Widerlov E, Bissette G, Walleus H, Karlsson I, Eklund K, et al. Elevated concentrations of CSF corticotropin-releasing factor-like immunoreactivity in depressed patients. Science (1984) 226:1342-4. doi:10.1126/science. 6334362

314. Gold PW, Calabrese JR, Kling MA, Avgerinos P, Khan I, Gallucci WT, et al. Abnormal ACTH and cortisol responses to ovine corticotropin releasing factor in patients with primary affective disorder. Prog Neuropsychopharmacol Biol Psychiatry (1986) 10:57-65. doi:10.1016/0278-5846(86)90044-8

315. Young EA, Haskett RF, Murphy-Weinberg V, Watson SJ, Akil H. Loss of glucocorticoid fast feedback in depression. Arch Gen Psychiatry (1991) 48:693-9. doi:10.1001/archpsyc.1991.01810320017003

316. Arborelius L, Owens MJ, Plotsky PM, Nemeroff CB. The role of corticotropinreleasing factor in depression and anxiety disorders. J Endocrinol (1999) 160:1-12. doi:10.1677/joe.0.1600001

317. Heim C, Newport DJ, Heit S, Graham YP, Wilcox M, Bonsall R, et al. Pituitaryadrenal and autonomic responses to stress in women after sexual and physical abuse in childhood. JAMA (2000) 284:592-7. doi:10.1001/jama.284.5.592

318. Heim C, Nemeroff CB. Neurobiology of early life stress: clinical studies. Semin Clin Neuropsychiatry (2002) 7:147-59. doi:10.1053/scnp.2002.33127

319. Heim C, Newport DJ, Mletzko T, Miller AH, Nemeroff CB. The link between childhood trauma and depression: insights from HPA axis studies in humans. Psychoneuroendocrinology (2008) 33:693-710. doi:10.1016/j.psyneuen.2008. 03.008

320. Kraemer GW, Ebert MH, Schmidt DE, McKinney WT. A longitudinal study of the effect of different social rearing conditions on cerebrospinal fluid norepinephrine and biogenic amine metabolites in rhesus monkeys. Neuropsychopharmacology (1989) 2:175-89. doi:10.1016/0893-133X(89)90021-3

321. Rosenblum LA, Andrews MW. Influences of environmental demand on maternal behavior and infant development. Acta Paediatr Suppl (1994) 397:57-63 doi:10.1111/j.1651-2227.1994.tb13266.x

322. Coplan JD, Andrews MW, Rosenblum LA, Owens MJ, Friedman S, Gorman JM, et al. Persistent elevations of cerebrospinal fluid concentrations of corticotropin-releasing factor in adult nonhuman primates exposed to early-life stressors: implications for the pathophysiology of mood and anxiety disorders. Proc Natl Acad Sci U S A (1996) 93:1619-23. doi:10.1073/pnas. 93.4.1619
323. Coplan JD, Trost RC, Owens MJ, Cooper TB, Gorman JM, Nemeroff CB, et al. Cerebrospinal fluid concentrations of somatostatin and biogenic amines in grown primates reared by mothers exposed to manipulated foraging conditions. Arch Gen Psychiatry (1998) 55:473-7. doi:10.1001/archpsyc.55.5.473

324. Maestripieri D, Higley JD, Lindell SG, Newman TK, McCormack KM, Sanchez MM. Early maternal rejection affects the development of monoaminergic systems and adult abusive parenting in rhesus macaques (Macaca mulatta). Behav Neurosci (2006) 120:1017-24. doi:10.1037/0735-7044.120.5.1017

325. Bremner JD, Krystal JH, Southwick SM, Charney DS. Noradrenergic mechanisms in stress and anxiety. I. Preclinical studies. Synapse (1996) 23:28-38. doi:10.1002/(SICI) 1098-2396(199605)23:1<28::AID-SYN4>3.3.CO;2-4

326. Bremner JD, Krystal JH, Southwick SM, Charney DS. Noradrenergic mechanisms in stress and anxiety. II. Clinical studies. Synapse (1996) 23:39-51. doi:10.1002/(SICI) 1098-2396(199605)23:1<28::AID-SYN4>3.3.CO;2-4

327. Heim C, Owens MJ, Plotsky PM, Nemeroff CB. The role of early adverse life events in the etiology of depression and posttraumatic stress disorder. Focus on corticotropin-releasing factor. Ann N Y Acad Sci (1997) 821:194-207. doi:10.1111/j.1749-6632.1997.tb48279.x

328. Porsolt RD, Brossard G, Hautbois C, Roux S. Rodent models of depression: forced swimming and tail suspension behavioral despair tests in rats and mice. Curr Protoc Neurosci (2001) Chapter 8:Unit810A. doi:10.1002/0471142301. ns0810as14

329. Pollak DD, Rey CE, Monje FJ. Rodent models in depression research: classical strategies and new directions. Ann Med (2010) 42:252-64. doi:10.3109/ 07853891003769957

330. Porsolt RD, Le Pichon M, Jalfre M. Depression: a new animal model sensitive to antidepressant treatments. Nature (1977) 266:730-2. doi:10.1038/266730a0

331. McEwen BS. Early life influences on life-long patterns of behavior and health Ment Retard Dev Disabil Res Rev (2003) 9:149-54. doi:10.1002/mrdd.10074

332. Cicchetti D, Toth SL. Child maltreatment. Annu Rev Clin Psychol (2005) 1:409-38. doi:10.1146/annurev.clinpsy.1.102803.144029

333. Pryce CR, Ruedi-Bettschen D, Dettling AC, Weston A, Russig H, Ferger B, et al. Long-term effects of early-life environmental manipulations in rodents and primates: potential animal models in depression research. Neurosci Biobehav $\operatorname{Rev}$ (2005) 29:649-74. doi:10.1016/j.neubiorev.2005.03.011

334. Heim C, Shugart M, Craighead WE, Nemeroff CB. Neurobiological and psychiatric consequences of child abuse and neglect. Dev Psychobiol (2010) 52:671-90. doi:10.1002/dev.20494

335. Hart J, Gunnar M, Cicchetti D. Altered neuroendocrine activity in maltreated children related to symptoms of depression. Dev Psychopathol (1996) 8:201-14. doi:10.1017/S0954579400007045

336. Heim C, Nemeroff CB. The impact of early adverse experiences on brain systems involved in the pathophysiology of anxiety and affective disorders. Biol Psychiatry (1999) 46:1509-22. doi:10.1016/S0006-3223(99)00224-3

337. Costello EJ, Pine DS, Hammen C, March JS, Plotsky PM, Weissman MM, et al. Development and natural history of mood disorders. Biol Psychiatry (2002) 52:529-42. doi:10.1016/S0006-3223(02)01372-0

338. Paus T, Keshavan M, Giedd JN. Why do many psychiatric disorders emerge during adolescence? Nat Rev Neurosci (2008) 9:947-57. doi:10.1038/nrn2513

339. Sevelinges Y, Moriceau S, Holman P, Miner C, Muzny K, Gervais R, et al. Enduring effects of infant memories: infant odor-shock conditioning attenuates amygdala activity and adult fear conditioning. Biol Psychiatry (2007) 62:1070-9. doi:10.1016/j.biopsych.2007.04.025

340. Sevelinges Y, Sullivan RM, Messaoudi B, Mouly AM. Neonatal odor-shock conditioning alters the neural network involved in odor fear learning at adulthood. Learn Mem (2008) 15:649-56. doi:10.1101/lm.998508

341. Moriceau S, Raineki C, Holman JD, Holman JG, Sullivan RM. Enduring neurobehavioral effects of early life trauma mediated through learning and corticosterone suppression. Front Behav Neurosci (2009) 3:22. doi:10.3389/neuro. 08.022.2009

342. Sevelinges Y, Mouly AM, Raineki C, Moriceau S, Forest C, Sullivan RM. Adult depression-like behavior, amygdala and olfactory cortex functions are restored by odor previously paired with shock during infant's sensitive period attachment learning. Dev Cogn Neurosci (2011) 1:77-87. doi:10.1016/j.dcn.2010.07. 005

343. Haynes-Seman C. Developmental origins of moral masochism: a failure-tothrive toddler's interactions with mother. Child Abuse Negl (1987) 11:319-30. doi:10.1016/0145-2134(87)90005-6 
344. Zeanah CH, Keyes A, Settles L. Attachment relationship experiences and childhood psychopathology. Ann N Y Acad Sci (2003) 1008:22-30. doi:10.1196/ annals. 1301.003

345. Bos KJ, Fox N, Zeanah CH, Nelson CA III. Effects of early psychosocial deprivation on the development of memory and executive function. Front Behav Neurosci (2009) 3:16. doi:10.3389/neuro.08.016.2009

346. Anand KJ, Coskun V, Thrivikraman KV, Nemeroff CB, Plotsky PM. Long-term behavioral effects of repetitive pain in neonatal rat pups. Physiol Behav (1999) 66:627-37. doi:10.1016/S0031-9384(98)00338-2

Conflict of Interest Statement: The authors declare that the research was conducted in the absence of any commercial or financial relationships that could be construed as a potential conflict of interest.
Received: 15 December 2013; paper pending published: 08 February 2014; accepted: 05 March 2014; published online: 21 March 2014.

Citation: Rincón-Cortés M and Sullivan RM (2014) Early life trauma and attachment: immediate and enduring effects on neurobehavioral and stress axis development. Front. Endocrinol. 5:33. doi: 10.3389/fendo.2014.00033

This article was submitted to Neuroendocrine Science, a section of the journal Frontiers in Endocrinology.

Copyright (C) 2014 Rincón-Cortés and Sullivan. This is an open-access article distributed under the terms of the Creative Commons Attribution License (CC BY). The use, distribution or reproduction in other forums is permitted, provided the original author(s) or licensor are credited and that the original publication in this journal is cited, in accordance with accepted academic practice. No use, distribution or reproduction is permitted which does not comply with these terms. 